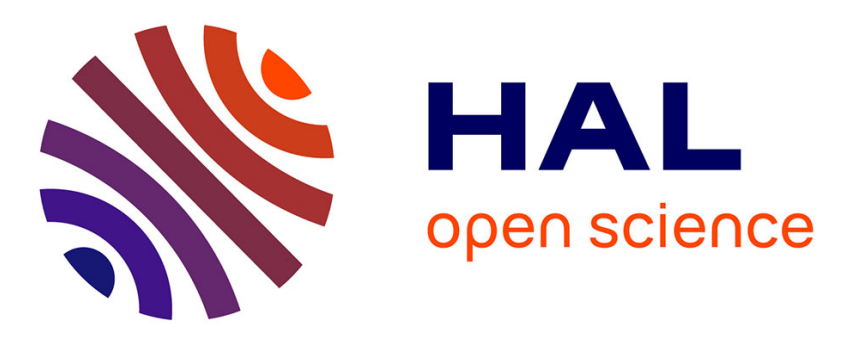

\title{
Preparation and characterization of nanosized magnesium ferrite powders by a starch-gel process and corresponding ceramics
}

Roberto Köferstein, Till Walther, Dietrich Hesse, Stefan G Ebbinghaus

\section{- To cite this version:}

Roberto Köferstein, Till Walther, Dietrich Hesse, Stefan G Ebbinghaus. Preparation and characterization of nanosized magnesium ferrite powders by a starch-gel process and corresponding ceramics. Journal of Materials Science, 2013, 48 (19), pp.6509-6518. 10.1007/s10853-013-7447-x . hal-01995695

\section{HAL Id: hal-01995695 \\ https://hal.science/hal-01995695}

Submitted on 27 Jan 2019

HAL is a multi-disciplinary open access archive for the deposit and dissemination of scientific research documents, whether they are published or not. The documents may come from teaching and research institutions in France or abroad, or from public or private research centers.
L'archive ouverte pluridisciplinaire HAL, est destinée au dépôt et à la diffusion de documents scientifiques de niveau recherche, publiés ou non, émanant des établissements d'enseignement et de recherche français ou étrangers, des laboratoires publics ou privés. 


\title{
Journal of Material Science (2013) 48:6509-6518 \\ (DOI 10.1007/s10853-013-7447-x)
}

\section{http://link.springer.com/article/10.1007/s10853-013-7447-x}

\section{Preparation and characterization of nano-sized magnesium ferrite powders by a starch-gel process and corresponding ceramics}

\author{
Roberto Köferstein $^{\mathrm{a},{ }^{*}}$, Till Walther ${ }^{\mathrm{a}}$, Dietrich Hesse ${ }^{\mathrm{b}}$, Stefan G. Ebbinghaus ${ }^{\mathrm{a}}$ \\ ${ }^{a}$ Institute of Chemistry, Inorganic Chemistry, Martin-Luther-University Halle-Wittenberg, \\ Kurt-Mothes-Strasse 2, 06120 Halle, Germany. \\ ${ }^{b}$ Max Planck Institute of Microstructure Physics, Weinberg 2, 06120 Halle, Germany. \\ * Corresponding author. Tel.: +49-345-5525630; Fax: +49-345-5527028. \\ E-mail address: roberto.koeferstein@ chemie.uni-halle.de
}

\begin{abstract}
The synthesis and characterization of nano-sized $\mathrm{MgFe}_{2} \mathrm{O}_{4}$ by a starch-gel method is described herein. A phase-pure nano-sized $\mathrm{MgFe}_{2} \mathrm{O}_{4}$ powder (1a) was obtained after calcining a $(\mathrm{MgFe})$-starch gel at $550{ }^{\circ} \mathrm{C}$. The powder has a specific surface area of $60.6 \mathrm{~m}^{2} / \mathrm{g}$ and a crystallite size of $9 \mathrm{~nm}$. TEM investigations reveal particles in the range of 7 to $15 \mathrm{~nm}$. The activation energy of the crystallite growth process was calculated as $89 \pm 14 \mathrm{~kJ} / \mathrm{mol}$. The shrinkage and sintering behaviour of resulting compacts were studied. UV-VIS investigations of the nano-sized powder 1a reveal an optical band gap of $2.38 \mathrm{eV}$, whereas calcination at $1100{ }^{\circ} \mathrm{C}$ (powder $\mathbf{1 g}$ ) leads to a crystallite size of $129 \mathrm{~nm}$ and a band gap of $2.16 \mathrm{eV}$. Magnetization loops at $300 \mathrm{~K}$ and the temperature dependence of both the field-cooled (FC)
\end{abstract}


and the zero-field-cooled (ZFC) magnetization indicate a superparamagnetic behaviour. The blocking temperature for powder $1 \mathrm{a}$ was determined as $140 \mathrm{~K}$ at a field of $\mathrm{H}=500 \mathrm{Oe}$. We found different saturation magnetizations $\left(\mathrm{M}_{\mathrm{s}}\right)$ depending on the calcination temperature. Calcination at $550{ }^{\circ} \mathrm{C}$ (1a) results in $\mathrm{M}_{\mathrm{s}}=20.0 \mathrm{emu} / \mathrm{g}$ which increases with calcination temperature to a maximum of $37.7 \mathrm{emu} / \mathrm{g}$ for powder $1 \mathrm{e}$ calcined at $900{ }^{\circ} \mathrm{C}$. Ceramic bodies sintered between 1450 and $1600{ }^{\circ} \mathrm{C}$ exhibit $\mathrm{M}_{\mathrm{s}}$ values of 25-28 emu/g. Magnetic investigations at $10 \mathrm{~K}$ on powders $\mathbf{1 a}-\mathbf{1 g}$ show hysteresis loops with coercivities up to 950 Oe, remanences to $10 \mathrm{emu} / \mathrm{g}$ and $\mathrm{M}_{\mathrm{s}}$ values to $50.4 \mathrm{emu} / \mathrm{g}$. Additionally, the nano-scaled powders show a shift of the hysteresis loops.

Keywords: soft-chemistry synthesis; sintering; magnetic properties; optical properties; spinel

\section{Introduction}

Magnesium ferrite $\left(\mathrm{MgFe}_{2} \mathrm{O}_{4}\right)$ is an important functional magnetic material which crystallizes in the spinel structure type. $\mathrm{MgFe}_{2} \mathrm{O}_{4}$-based materials have found applications in microwave devices, computer memory chips and high-density recording media [1,2]. $\mathrm{MgFe}_{2} \mathrm{O}_{4}$ can also be used as catalyst for the oxidation of styrene [3], the dechlorination of polychlorinated aromatic compounds [4], and the decomposition of carbon particulates [5]. Dom et al. [6] investigated the photocatalytic activity and Xiong et al. [7] showed a catalytic effect of magnesium ferrite in a heterogeneous Fenton-like reaction.

Furthermore, $\mathrm{MgFe}_{2} \mathrm{O}_{4}$ finds application as gas- and humidity sensor [8,9], as semiconductor [10], and is also used as an inorganic pigment $[11,12,13]$. In addition it has been shown that $\mathrm{MgFe}_{2} \mathrm{O}_{4}$ is a promising candidate for local heat treatment in human cancer therapy $[14,15]$. Okawa et al. [16] used $\mathrm{MgFe}_{2} \mathrm{O}_{4}$ as cathode material in a molten carbonate fuel cell (MCFC). Moreover, composite materials consisting of $\mathrm{MgFe}_{2} \mathrm{O}_{4}$ and $\mathrm{BaTiO}_{3}$ show multiferroic properties [17]. 
$\mathrm{MgFe}_{2} \mathrm{O}_{4}$ is a soft-magnetic n-type semiconducting material with a Néel temperature of around $400{ }^{\circ} \mathrm{C}[18,19]$. The crystal structure lies between a normal spinel and an inverse spinel type and the fraction of tetrahedral sites occupied by $\mathrm{Fe}^{3+}$-ions depends on the temperature $[18,19,20]$. For this reason the chemical formula of magnesium ferrite can be written as ${ }^{\mathrm{T}}\left(\mathrm{Mg}_{1-x} \mathrm{Fe}_{x}\right)^{\mathrm{O}}\left(\mathrm{Mg}_{x} \mathrm{Fe}_{2-x}\right) \mathrm{O}_{4}$, where $\mathrm{T}$ and $\mathrm{O}$ represent the tetrahedral and octahedral sites of the spinel-type structure, respectively. The inversion parameter $x$ reflects the fraction of iron cations occupying the tetrahedral site $[18,19]$.

To synthesise $\mathrm{MgFe}_{2} \mathrm{O}_{4}$ nanoparticles various chemical and physical approaches are reported such as high-energy ball milling [21], sol-gel [22], micelle [23,24], polymerization/coprecipitate [5,25,26] and combustion methods [27]. An electrospinning procedure was published by Maensiri et al. [28].

The aim of this paper is to describe a versatile and cheap one-pot synthesis route to obtain nano-sized $\mathrm{MgFe}_{2} \mathrm{O}_{4}$ by decomposition of a $(\mathrm{MgFe})$-gel using starch both as gellant and complexation agent. We have examined the decomposition process to $\mathrm{MgFe}_{2} \mathrm{O}_{4}$ via thermogravimetry (TG), mass spectroscopy (MS), and differential thermal analysis (DTA). Phase evolution and grain growth kinetics during the formation of $\mathrm{MgFe}_{2} \mathrm{O}_{4}$ have been investigated by X-ray powder diffraction (XRD). For the obtained powders of various particle sizes optical band gaps, magnetic properties, and the sintering behaviour yielding dense compacts have also been studied.

\section{Experimental}

\subsection{Material preparation}

$\mathrm{Mg}\left(\mathrm{NO}_{3}\right)_{2} \cdot 6 \mathrm{H}_{2} \mathrm{O}(0.006 \mathrm{~mol}$, Alfa Aesar, $>98 \%)$ and $\mathrm{Fe}\left(\mathrm{NO}_{3}\right)_{3} \cdot 9 \mathrm{H}_{2} \mathrm{O}(0.012 \mathrm{~mol}$, Merck, ACS) were dissolved in $15 \mathrm{ml}$ water. $2 \mathrm{~g}$ soluble starch (Sigma-Aldrich, p.a) were added and the mixture was stirred on a heating plate for $15 \mathrm{~min}$ at room temperature. Afterwards the 
temperature was raised to about $120-140{ }^{\circ} \mathrm{C}$ and the mixture was stirred and heated until it turned into a highly viscous red gel.

This $(\mathrm{MgFe})$-gel was calcined in static air at various temperatures for $2 \mathrm{~h}$ with a heating rate of $5 \mathrm{~K} / \mathrm{min}$ to yield $\mathrm{MgFe}_{2} \mathrm{O}_{4}$ powders (1a-1f) with different particle sizes.

For comparative purposes, a coarse-grained $\mathrm{MgFe}_{2} \mathrm{O}_{4}$ powder (2) was prepared via the conventional mixed-oxide method. Stoichiometric amounts of $\mathrm{Fe}_{2} \mathrm{O}_{3}$ (Sigma-Aldrich, $99 \%$ ) and $\mathrm{MgO}$ (Sigma-Aldrich, $99 \%$ ) were well ground together in an agate mortar and fired at $1250{ }^{\circ} \mathrm{C}$ for $24 \mathrm{~h}$ in static air.

Tab. 1 summarizes the synthesis conditions of the $\mathrm{MgFe}_{2} \mathrm{O}_{4}$ powders.

For the sintering investigations, powder 1a and 2 were mixed with 5 wt $\%$ of a saturated aqueous polyvinyl alcohol (PVA) solution as pressing aid and then the powders were pressed into pellets.

\subsection{Characterization}

X-ray powder diffraction patterns with a step size of $2 \theta=0.01^{\circ}$ were collected at room temperature on a Bruker D8-Advanced diffractometer, equipped with a one-dimensional silicon strip detector (LynxEye $\left.{ }^{\mathrm{TM}}\right)$ and operating with $\mathrm{Cu}-\mathrm{K}_{\alpha}$ radiation. Powder patterns were refined with the profile fitting software PowderCell [29]. Crystallite sizes were determined from the XRD line broadening using the Scherrer equation and the integral peak breadth (software suite WinXPOW [30]). The Wilson-equation was used to determine the strain parameter [30,31]. Dilatometric (shrinkage) investigations were performed in a flowing synthetic air atmosphere $(50 \mathrm{ml} / \mathrm{min})$ in a Setaram TMA 92-16.18 dilatometer. Simultaneous thermogravimetric (TG), mass spectrometry (MS) and differential thermoanalytic (DTA) measurements in flowing synthetic air $(30 \mathrm{ml} / \mathrm{min})$ were performed using a Netzsch STA 449 
system equipped with a quadrupole mass spectrometer ESD 100 (InProcess Instruments). The thermoanalytic measurements of the decomposition of the $(\mathrm{MgFe})$-gel were carried out on a sample preheated at $200{ }^{\circ} \mathrm{C}$ for $1 \mathrm{~h}$. The specific surface area (BET) was determined using nitrogen five-point gas-physisorption (Nova 1000, Quantachrome Corporation). The equivalent BET particle diameters were calculated assuming a spherical or cubic particle shape [32]. ATR-Fourier transformed infrared (FT-IR) spectra were collected at room temperature using a Bruker Tensor 27 spectrometer equipped with a diamond ATR unit. Transmission electron microscopy (TEM) samples were prepared by dispersing the powder in alcohol under ultrasonic agitation, and collecting it onto a copper TEM grid covered with a carbon membrane. TEM images were recorded with a Philips CM20Twin at an electron energy of $200 \mathrm{keV}$. Scanning electron microscope images were recorded with a Philips XL30 ESEM (Environmental Scanning Electron Microscope). Diffuse reflectance spectra were obtained at room temperature in the range 380-1000 nm using a Perkin Elmer UV-VIS spectrometer Lambda 19. $\mathrm{BaSO}_{4}$ was used as a white standard. Magnetic measurements were carried out using a PPMS 9 from Quantum Design. Hysteresis loops were taken at $300 \mathrm{~K}$ and $10 \mathrm{~K}$ with magnetic field cycling between -90 and $+90 \mathrm{kOe}$. In addition, the temperature dependent magnetic moments were measured at $\mathrm{H}=500$ Oe in the temperature range of 5 to $300 \mathrm{~K}$ using field-cooled (FC) and zero-field cooled (ZFC) conditions.

\section{Results and discussion}

\subsection{Thermal analysis}

Heating of the $(\mathrm{MgFe})$-gel at $200{ }^{\circ} \mathrm{C}$ for $1 \mathrm{~h}$ in air resulted in a black-brown powder. Simultaneous TG-MS and DTA investigations up to $700{ }^{\circ} \mathrm{C}$ in flowing air (heating rate: 5 $\mathrm{K} / \mathrm{min}$ ) were carried out on this powder (Fig. 1a). We detected a weight loss of $7.5 \%$ up to $250{ }^{\circ} \mathrm{C}$ by the evaporation of water from the surface, due to the hygroscopic nature of the sample. The DTA curve shows a very weak endothermic signal and the MS curve has a weak 
signal for $\mathrm{m} / \mathrm{z}=18$ (see inset in Fig. 1a). The strongly exothermic reaction between 285 and $319{ }^{\circ} \mathrm{C}$ is accompanied by a total weight loss of $49.2 \%$. This exothermic reaction is characterized by the evolution of $\mathrm{CO}_{2}, \mathrm{H}_{2} \mathrm{O}, \mathrm{NO}_{2}$, and $\mathrm{NO}$ and suggests a self-combustion like process in which the nitrate ions act as an oxidizing agent and the (partly decomposed) starch molecules as fuel. A proceeding second weaker exothermic process is finished at $408{ }^{\circ} \mathrm{C}$. Simultaneous mass spectroscopy indicated the evaporation of small amounts of $\mathrm{CO}_{2}, \mathrm{NO}_{2}$, and NO. A very slight last weight loss is completed at about $600{ }^{\circ} \mathrm{C}$ and the total weight loss accounts to $56.8 \%$. XRD investigations on the final brown product indicated phase-pure cubic $\mathrm{MgFe}_{2} \mathrm{O}_{4}[33]$.

Fig. 1b shows TG/DTA measurements of the same powder as above but in argon atmosphere and up to $900{ }^{\circ} \mathrm{C}$ (heating rate: $5 \mathrm{~K} / \mathrm{min}$ ). Up to $500{ }^{\circ} \mathrm{C}$ we observed a weight loss of $51.3 \%$. $\mathrm{XRD}$ investigation of the black intermediate at $500{ }^{\circ} \mathrm{C}$ revealed weak reflections of $\mathrm{FeO}$ and elemental iron [33]. A last decomposition process between 570 and $830{ }^{\circ} \mathrm{C}$ led to a total weight loss of $64.0 \%$. The decomposition processes are accompanied by two endothermic signals. In contrast to the thermoanalytic measurements in air the decomposition in argon atmosphere results in a mixture of $\mathrm{MgFe}_{2} \mathrm{O}_{4}, \mathrm{Mg}_{1-\mathrm{x}} \mathrm{Fe}_{\mathrm{x}} \mathrm{O}$ [33] and elemental iron. The formation of both elemental iron and $\mathrm{Mg}_{1-\mathrm{x}} \mathrm{Fe}_{\mathrm{x}} \mathrm{O}$ was also observed in the reduction of $\mathrm{MgFe}_{2} \mathrm{O}_{4}$ with $\mathrm{H}_{2}$ [34]. The decomposition in argon atmosphere shows that atmospheric oxygen is essential for that combustion-like decomposition process to prepare phase-pure $\mathrm{MgFe}_{2} \mathrm{O}_{4}$

\subsection{XRD, TEM, IR}

Fig. 2 shows the phase evolution during the thermal decomposition of the red (MgFe)-gel. For these XRD investigations the samples of the (MgFe)-gel were heated in a muffle furnace in static air at various temperatures for $2 \mathrm{~h}$ (heating rate $5 \mathrm{~K} / \mathrm{min}$ ) resulting in fluffy powders. The as-prepared (MgFe)-gel is X-ray amorphous (Graph 2a). Up to a calcination temperature 
of $400{ }^{\circ} \mathrm{C}$ we obtained only a weak and broad reflection around $2 \theta \approx 35^{\circ}$ possibly due to the presence of $\mathrm{Fe}_{2} \mathrm{O}_{3}$ [33]. Broad reflections of pure cubic $\mathrm{MgFe}_{2} \mathrm{O}_{4}$ [33] appeared after a thermal treatment at $550{ }^{\circ} \mathrm{C}$ (Graph 2c). The resulting powder (1a) has a BET specific surface area of $60.6 \mathrm{~m}^{2} / \mathrm{g}$ corresponding to an equivalent particle size of $22 \mathrm{~nm}$, which can be considered as the average size of the primary particles [35]. The volume-weighted average crystallite size (Scherrer equation) was calculated to be $9 \mathrm{~nm}$. According to the Wilson-equation [31] the root-mean-square strain was found to be $5 \cdot 5 \cdot 10^{3}$ (see also Tab. 1). The calculated crystallite size is roughly by the factor two smaller than the size of the primary particles obtained from the BET data because the calcination procedure of the $(\mathrm{MgFe})$-gel leads to closely joined crystallites and surface areas unavailable for nitrogen adsorption [32]. TEM investigations (Fig. 3) of powder 1a mainly show particles in the range of 7 to $15 \mathrm{~nm}$ as well as a small fraction of larger particles up to $20 \mathrm{~nm}$. Graphs $2 \mathrm{~d}$ and 2e exemplarily show XRD patterns of powders 1c and 1f calcined at 700 and $1100{ }^{\circ} \mathrm{C}$, respectively. With higher calcination temperature the resulting powders show a decreasing specific surface area and increasingly crystallite sizes. The root-mean-square-strain is reduced with raising calcination temperature and is almost constant from 900 to $1100{ }^{\circ} \mathrm{C}$ (see Tab. 1).

The kinetics of crystallite growth can be expressed by the following phenomenological equation (1) [36]:

$D^{m}-D_{0}{ }^{m}=k t \cdot e \frac{-E_{A}}{R T}$

where $D_{0}$ is the initial crystallite size, $D$ the crystallite size after calcination for the time $t$ and at temperature $T, k$ is the pre-exponential constant, $m$ the crystallite growth exponent, $E_{A}$ the activation energy for the crystallite growth process and $R$ the universal gas constant.

The initial crystallite size $D_{0}$ is usually negligibly small, therefore equation 1 can be simplified to: 
$D^{m}=k t \cdot \mathrm{e} \frac{-E_{A}}{R T}$

The kinetic crystallite growth exponent $m$ can be determined from the inverse slope of $\ln D$ vs. $\ln t$. For that purpose we estimated the crystallite sizes after calcining the $(\mathrm{MgFe})$-gel at 600 ${ }^{\circ} \mathrm{C}$ for different times from $2 \mathrm{~h}$ up to $100 \mathrm{~h}$. From Fig. 4a the crystallite growth exponent was found to be $m=7.7$. The activation energy of the crystallite growth process during the calcination can be calculated from the slope of an Arrhenius plot $\left(\ln D^{7.7} / t\right.$ vs. $\left.1 / T\right)$ as shown in Fig. 4b. It was calculated as $E_{A}=89 \pm 14 \mathrm{~kJ} / \mathrm{mol}$.

Fig. 5 represents FT-IR spectra (ATR technique) of the (MgFe)-gel, corresponding calcination products at $550{ }^{\circ} \mathrm{C}$ (powder 1a) and $1000{ }^{\circ} \mathrm{C}$ (powder 1f). The broad band between about 3700 and $2600 \mathrm{~cm}^{-1}$ in the spectrum of the (MgFe)-gel (Graph 5a) is caused by $\mathrm{O}-\mathrm{H}$ stretching and $\mathrm{C}-\mathrm{H}$ stretching vibrations from water and starch molecules [37]. The $\mathrm{O}-\mathrm{H}$ bending mode is reflected by an absorption band at $1635 \mathrm{~cm}^{-1}$ [38]. Anti-symmetric and symmetric $\mathrm{N}-\mathrm{O}$ vibrations from $\mathrm{NO}_{3}^{-}$- ions appear at $1339 \mathrm{~cm}^{-1}$ and as a shoulder at $1042 \mathrm{~cm}^{-}$ ${ }^{1}$ [38]. The additional shoulder at $1406 \mathrm{~cm}^{-1}$ represents $\mathrm{O}-\mathrm{C}-\mathrm{H}, \mathrm{C}-\mathrm{C}-\mathrm{H}$, and $\mathrm{C}-\mathrm{O}-\mathrm{H}$ bending modes from the starch [37]. C-O-H groups cause $\mathrm{C}-\mathrm{O}$ stretching vibrations at $1152 \mathrm{~cm}^{-1}$, whereas $\mathrm{C}-\mathrm{O}$ stretching modes from $\mathrm{C}-\mathrm{O}-\mathrm{C}$ groups appear at 1080 and $1022 \mathrm{~cm}^{-1}$ [39].

The IR spectra of powder 1a and $\mathbf{1 f}$ show two characteristic adsorption bands $v_{1}$ and $v_{2}$ (Graph 5b,c) The higher frequency band $\left(v_{1}\right)$, which appears at $539(\mathbf{1 a})$ and $536 \mathrm{~cm}^{-1}(\mathbf{1 f})$ can be assigned to an iron-oxygen stretching vibration on the tetrahedral site. The lower frequency band $\left(v_{2}\right)$ at $395(\mathbf{1 a})$ and $402 \mathrm{~cm}^{-1}(\mathbf{1 f})$ is caused by the iron-oxygen stretching vibration on the octahedral site [40]. According to Josyulu and Sobhanadri [41] the weak absorption band at around 350 and $360 \mathrm{~cm}^{-1}\left(v_{3}\right)$ stems from a magnesium-oxygen stretching vibration on the octahedral site. 
The XRD patterns of the nano-powder 1a was refined on the basis of a cubic unit cell (space group: Fd-3m) [42] and the cell parameter was calculated as a $=838.40 \mathrm{pm}$, which corresponds well to previously reported data for $\mathrm{MgFe}_{2} \mathrm{O}_{4}[18,42]$.

\subsection{Sintering behaviour and microstructure}

Fig. 6 shows the non-isothermal dilatometric investigations up to $1550{ }^{\circ} \mathrm{C}$ in flowing air (heating rate: $10 \mathrm{~K} / \mathrm{min})$. Since the green compacts $1 \mathbf{a}\left(2.0 \mathrm{~g} / \mathrm{cm}^{3}\right)$ and $\mathbf{2}\left(3.3 \mathrm{~g} / \mathrm{cm}^{3}\right)$ strongly differ in their densities the values of the relative shrinkage are not directly comparable. Therefore, from the relative shrinkages the evolution of the relative densities was calculated assuming an isotropic behaviour of the compacts.

The shrinkage behaviour of compact 1a reveals a distinctive two-step characteristic. A first shrinkage process starts at about $610{ }^{\circ} \mathrm{C}$ and has a maximum of the shrinkage rate of -0.86 $\% /$ min at $820{ }^{\circ} \mathrm{C}$. The second step begins at $1150{ }^{\circ} \mathrm{C}$ and shows a shrinkage rate maximum at $1323(-0.28 \% / \mathrm{min})$. The first step accounts to about $60 \%$ of the total shrinkage. The rates of both shrinkage steps are more than $0.1 \% / \mathrm{min}$ indicating sliding processes (viscous flow) as dominant shrinkage mechanism, primarily caused by the nano particles $[43,44]$. Between the two shrinkage steps there is a plateau at about $950-1150{ }^{\circ} \mathrm{C}$ where the shrinkage is very small. According to investigations of Hirata et al. [45] we assume that this stage is dominated by grain growth within secondary particles (agglomerate) in such a way that almost no pores are eliminated. The final calculated relative density reaches $85 \%$ at $1550{ }^{\circ} \mathrm{C}$.

For comparison purposes we also investigated a coarse-grained $\mathrm{MgFe}_{2} \mathrm{O}_{4}$ powder (2). That powder (Graph 2f) results from a conventional mixed-oxide synthesis at $1250{ }^{\circ} \mathrm{C}$ for $24 \mathrm{~h}$ and has a specific surface area of $1.1 \mathrm{~m}^{2} / \mathrm{g}$ and an equivalent particle size of $1215 \mathrm{~nm}$.

The shrinkage of compact 2 starts at approximately $1150{ }^{\circ} \mathrm{C}$ and a small shrinkage rate maximum of $-0.09 \% / \mathrm{min}$ appears at $1185^{\circ} \mathrm{C}$. At about $1380{ }^{\circ} \mathrm{C}$ the slope of the shrinkage curve changes, indicating a second shrinkage step, which is not yet finished up to $1550{ }^{\circ} \mathrm{C}$. 
The sample reaches a final relative density of $80 \%$. Since the low shrinkage rate of compact 2 is about $0.1 \%$, sliding processes play no important role during the sintering. Hence diffusion processes are more relevant during the densification of the micrometer-sized compact 2 than in the nano-particular compact 1a [44].

The final bulk densities of ceramic bodies of $\mathbf{1 a}$ after isothermal sintering at various temperatures with a soaking time of 1 and 10 h, respectively, are shown in Fig. 7. The bulk densities of the sintered bodies were calculated from their weight and geometric dimensions. The relative bulk densities (r.d.) of the ceramic bodies refer to the crystallographic density of $4.49 \mathrm{~g} / \mathrm{cm}^{3}$ [46]. After a soaking time of $1 \mathrm{~h}$ we obtain ceramic bodies with a relative density of $84 \%$ at $1450{ }^{\circ} \mathrm{C}$ (grain size: $3-15 \mu \mathrm{m}$, Fig. $8 \mathrm{a}$ ) and $88 \%$ at $1500{ }^{\circ} \mathrm{C}$ (grain size: $3.5-15$ $\mu \mathrm{m}$ ). Dense ceramic bodies (relative density $\geq 90 \%$ ) form only at a sintering temperature of $1550{ }^{\circ} \mathrm{C}(90 \%$, grain size: $6-18 \mu \mathrm{m})$ and a relative density of $94 \%$ is found at $1600{ }^{\circ} \mathrm{C}$ (grain size: $6-25 \mu \mathrm{m})$. However, a prolonged soaking time of $10 \mathrm{~h}$ leads to dense ceramic bodies even at $1450{ }^{\circ} \mathrm{C}(91 \%$, grain size: $4-28 \mu \mathrm{m}$, Fig. $8 \mathrm{~b})$. At $1500{ }^{\circ} \mathrm{C}$ and $1550{ }^{\circ} \mathrm{C}$ the relative densities are raised to 93 and $96 \%$ and the grain sizes are in the range of 5-42 and 16-50 $\mu \mathrm{m}$, respectively. EDX analysis on the surface of a compact sintered for $10 \mathrm{~h}$ at $1550{ }^{\circ} \mathrm{C}$ reveal some grains consisting of $\mathrm{MgO}$. The XRD pattern (not shown) of that ceramic shows reflections of cubic $\mathrm{MgFe}_{2} \mathrm{O}_{4}$ and traces of $\mathrm{MgO}$. These results are consistent with investigations reported by Phillips et al. [47]. They found in samples after equilibration at $\geq$ $1500{ }^{\circ} \mathrm{C}$ besides the main phase $\mathrm{MgFe}_{2} \mathrm{O}_{4}$ the secondary $\mathrm{MgO}$ phase. Ahmed et al. [48] sintered a conventional mixed-oxide $\mathrm{MgFe}_{2} \mathrm{O}_{4}$ powder at $1550{ }^{\circ} \mathrm{C}$ for $2 \mathrm{~h}$ and obtained a ceramic body with a density of $3.71 \mathrm{~g} / \mathrm{cm}^{3}(83 \%)$.

From these experiments it is evident that the nano-crystalline $\mathrm{MgFe}_{2} \mathrm{O}_{4}$ prepared from the decomposition of the starch precursor shows improved sintering properties, which is 
advantageous for all applications that require dense ceramics, such as in microwave devices $[1,49]$.

\subsection{Magnetic measurements}

Table 2 summarizes the magnetic data of the $\mathrm{MgFe}_{2} \mathrm{O}_{4}$ powders $\mathbf{1 a}-\mathbf{1 g}$. The evolution of magnetization $(\mathrm{M})$ depending on the applied field $(\mathrm{H})$ at $300 \mathrm{~K}$ is demonstrated in Fig. 9 for powders 1a, 1c, 1 e and $1 \mathrm{~g}$. The saturation magnetization $\left(\mathrm{M}_{\mathrm{s}}\right)$ was evaluated by extrapolation of the magnetization versus $1 / \mathrm{H}$ to $1 / \mathrm{H} \rightarrow 0$, according to the Law of Approach to Saturation [50]. Magnetic measurements at $300 \mathrm{~K}$ reveal a saturation magnetization for sample 1a of $\mathrm{M}_{\mathrm{s}}$ $=20.0 \mathrm{emu} / \mathrm{g}$, which increases with increasing crystallite size and/or calcination temperature and reaches a maximum of $\mathrm{M}_{\mathrm{s}}=37.7 \mathrm{emu} / \mathrm{g}$ at $900{ }^{\circ} \mathrm{C}$. Further calcinations at 1000 and 1100 ${ }^{\circ} \mathrm{C}$ and thus increasing crystallite sizes cause a gradual reduction of $\mathrm{M}_{\mathrm{s}}$ (inset in Fig. 9). It is well known that among other things $M_{s}$ is influenced by the crystallite size, the inversion parameter $(x)$, and surface effects (i.e. spin-glass like behaviour of the surface spins) $[23,51]$. With increasing particle size, surface effects are gradually reduced. Therefore the reduction of $\mathrm{M}_{\mathrm{s}}$ from crystallite sizes above $60 \mathrm{~nm}$ (powder $\mathbf{1 f}, \mathbf{1 g}$ ) is possibly dominated by an increase of $x[51,52]$.

The coercivity $\left(\mathrm{H}_{\mathrm{c}}\right)$ and remanence $\left(\mathrm{M}_{\mathrm{r}}\right)$ values for sample $\mathbf{1 a}$ and $\mathbf{1 b}$ are very small indicating a superparamagnetic behaviour [23] in accordance with the observed small crystallite sizes. The calculated $\mathrm{M}_{\mathrm{r}} / \mathrm{M}_{\mathrm{s}}$ ratios for all samples are lower than 0.1 indicating an appreciable fraction of superparamagnetic particles at $300 \mathrm{~K}$ [53]. Fig. 10 exemplarily shows the temperature dependence of the magnetization under zero-field-cooled (ZFC) and field-cooled (FC) conditions with an external field of 500 Oe for powder 1a. The magnetization of the FC curve decreases with increasing temperature, while the ZFC curve increases as temperature is increased up to a maximum corresponding to the blocking temperature $\left(\mathrm{T}_{\mathrm{B}}\right)$. Above the blocking temperature the ZFC curve starts to decrease. The formation of a maximum in the 
ZFC curve is a result of the superparamagnetic behaviour of the sample [54]. $T_{B}$ increases with the crystallite size from $140 \mathrm{~K}$ for powder $\mathbf{1 a}\left(\mathrm{d}_{\text {cryst }}=9 \mathrm{~nm}\right)$ to $210 \mathrm{~K}$ for powder $\mathbf{1 c}$ $\left(\mathrm{d}_{\text {cryst. }}=13 \mathrm{~nm}\right)$. Chen and Zhan [55] determined a blocking temperature for $\mathrm{MgFe}_{2} \mathrm{O}_{4}$ nanoparticles $(11 \mathrm{~nm})$ of about $170 \mathrm{~K}$, in good accordance with values found in this work.

Below the blocking temperature the field dependent magnetization of the $\mathrm{MgFe}_{2} \mathrm{O}_{4}$ powders show the formation of pronounced hysteresis loops. Fig. 11 shows $\mathrm{M}-\mathrm{H}$ loops at $10 \mathrm{~K}$ for powders 1a, 1c, 1e, and 1g, exemplarily. Values of the coercivity between 950 and 60 Oe and remanences between 10.3 and $5.0 \mathrm{emu} / \mathrm{g}$ were found, indicating a ferromagnetic behaviour (inset $\mathrm{I}$ in Fig. 11). $\mathrm{M}_{\mathrm{s}}$ values at $10 \mathrm{~K}$ are in the range from 28.3 to $50.4 \mathrm{emu} / \mathrm{g}$, whereas the dependence of $\mathrm{M}_{\mathrm{s}}$ on the crystallite size is analogous to the measurements at $300 \mathrm{~K}$ (inset II in Fig. 11). Closer inspection shows a small shift $\left(\Delta \mathrm{H}_{\mathrm{c}}\right)$ of the hysteresis loops (exchange biaslike) at $10 \mathrm{~K}$ of the nano-scaled $\mathrm{MgFe}_{2} \mathrm{O}_{4}$ powders (Tab. 2) in the negative direction, therefore we found different coercivity values for decreasing and increasing field as demonstrated for powder 1a in Fig. 12. Based on Nogues and Schuller [56] the coercivity shift is defined as $\Delta \mathrm{H}_{\mathrm{c}}=\left|0.5\left(\mathrm{H}_{\mathrm{c}(\mathrm{df})}+\mathrm{H}_{\mathrm{c}(\mathrm{if})}\right)\right|$, where $\mathrm{H}_{\mathrm{c}(\mathrm{df})}$ is the coercivity at decreasing field and $\mathrm{H}_{\mathrm{c}(\mathrm{if})}$ is the coercivity at increasing field. $\Delta \mathrm{H}_{\mathrm{c}}$ describes the shift of the centre (half width) of the hysteresis loop with respect to the origin $(H=0)$. Powder $1 \mathbf{a}$ with $\mathrm{d}_{\mathrm{cryst}}=8 \mathrm{~nm}$ has a loop shift of $\Delta \mathrm{H}_{\mathrm{c}}=81$ Oe, which decreases with increasing crystallite size (inset in Fig. 12). Loop shifts between 60-200 Oe were also found in high-energy milled nanocrystalline $\mathrm{MgFe}_{2} \mathrm{O}_{4}$ [52,57,58]. Loop shifts occur in materials with ferromagnetic/anti-ferromagnetic interfaces (exchange bias) [56]. Calculations on spherical NiO nano-particles by Kodama et al. [59] showed that the loop shift originates from the interaction between the reduced coordinated surface spins and the core. According to the core-shell model by Sepelak et al. [57] we can assume that the nanocrystalline $\mathrm{MgFe}_{2} \mathrm{O}_{4}$ consist of a ferrimagnetic core and a surface (grain 
boundary) with uncompensated spins. The exchange coupling between the core and the shell leads to the observed loop shift.

$\mathrm{M}-\mathrm{H}$ loops at $300 \mathrm{~K}$ of ceramic bodies sintered at $1450{ }^{\circ} \mathrm{C}$ for $1 \mathrm{~h}$ (grain size: $3-15 \mu \mathrm{m}$ ) reveal a $\mathrm{M}_{\mathrm{s}}$ value of $28.2 \mathrm{emu} / \mathrm{g}$, which only slightly decreases to about $26 \mathrm{emu} / \mathrm{g}$ after sintering at $\geq 1500{ }^{\circ} \mathrm{C}$ (Fig. 13, Tab. 3). Sintering for $10 \mathrm{~h}$ leads to the same tendency. Measurements at $10 \mathrm{~K}$ reveal saturation magnetizations between 32.7 and $35.9 \mathrm{emu} / \mathrm{g}$. Coercivity and remanence of the ceramic bodies do not differ significantly from zero and indicated a blocking temperature above $300 \mathrm{~K}$.

The coarse-grained powder 2 has a saturation magnetization of $28.2 \mathrm{emu} / \mathrm{g}$ at $300 \mathrm{~K}$ and 32.6 emu/g at $10 \mathrm{~K}$ and its magnetic behaviour is similar to the ceramic bodies described above. The saturation magnetizations both for the ceramic bodies and powder $\mathbf{2}$ are in good agreement with the reported $\mathrm{M}_{\mathrm{s}}$ value of $33 \mathrm{emu} / \mathrm{g}$ at $3 \mathrm{~K}$ for bulk $\mathrm{MgFe}_{2} \mathrm{O}_{4}$ [57].

\subsection{Diffuse reflectance measurements}

Reported band gaps for $\mathrm{MgFe}_{2} \mathrm{O}_{4}$ samples are in the range of 2.0-2.2 eV [10,60,61]. To determine the optical band gap of $\mathrm{MgFe}_{2} \mathrm{O}_{4}$ diffuse reflectance spectra were recorded in the range of 380 to $1000 \mathrm{~nm}$, as demonstrated in Fig. 14. The samples show a high reflectance in the visible range. The Kubelka-Munk theory was used for the analysis of diffuse reflectance spectra as expressed by the following equation $[62,63]$ :

$F(R)=\frac{(1-R)^{2}}{2 R}$

where $F(R)$ is the Kubelka-Munk function and $R$ the reflectance.

The optical band gap can be determined according to equation 5 [64]: 
$\alpha h v=k\left(h v-E_{g}\right)^{1 / n}$

where $\alpha$ is the absorption coefficient, which is proportional to $F(R), k$ is an energyindependent constant, $E_{g}$ the optical band gap. The exponent $n$ is determined by the type of transition: $n=2$ for direct allowed transitions, $n=2 / 3$ for direct forbidden transitions, $n=1 / 2$ for indirect allowed transitions and $n=1 / 3$ for indirect forbidden transitions.

The McLean analysis $[64,65]$ of the absorptions edge was applied to determine the exponent $n$ and thus the type of transition. In the range of the absorption edge $(F(R) \cdot h v)^{n} v s . h v$ should give a straight line. We found the best choice was $n=2$ for all samples indicating that the direct allowed transition is dominant in the samples. Hence equation 5 can be written as:

$F(R) \cdot h v=k\left(h v-E_{g}\right)^{1 / 2}$

The optical band gap $\left(E_{g}\right)$ can be determined by plotting $(F(R) \cdot h v)^{2} v s . h v$ and extrapolating the slope to $F(R) \rightarrow 0$ as exemplarily shown in the inset in Fig. 14 .

For powder 1a (calcination at $550{ }^{\circ} \mathrm{C}$ ) an optical band gap of $2.38 \pm 0.05 \mathrm{eV}$ was found, whereas calcination at $1100{ }^{\circ} \mathrm{C}$ (powder $1 \mathrm{~g}$ ) lead to a reduction of the band gap to $2.16 \pm 0.02$ $\mathrm{eV}$. The reduction is probably a result of the crystallite-/particle growth [66] (see also Tab. 1). The band gap energies of ceramic bodies sintered at $1450{ }^{\circ} \mathrm{C}$ and $1550{ }^{\circ} \mathrm{C}$ (soaking time $1 \mathrm{~h}$ ) do not significantly differ from each other and reveal slightly lower values of $2.11 \pm 0.02 \mathrm{eV}$ and $2.10 \pm 0.02 \mathrm{eV}$, respectively. On the other hand the coarse-grained mixed-oxide powder 2 has a band gap of $1.91 \pm 0.01 \mathrm{eV}$. The variation of the band gap with increasing particle size is an important aspect for photocatalytic applications of $\mathrm{MgFe}_{2} \mathrm{O}_{4}$ [6]. 


\section{Conclusion}

We prepared nano-sized $\mathrm{MgFe}_{2} \mathrm{O}_{4}$ powders by decomposition of a (MgFe)-gel obtained using starch as a gellant and complexation agent. Calcining in air of the $(\mathrm{MgFe})$-gel at $550{ }^{\circ} \mathrm{C}$ leads to a nano-crystalline powder (1a) with crystallite sizes of $9 \mathrm{~nm}$. TEM images show particles in the range of $7-15 \mathrm{~nm}$. The crystallite size increases to $116 \mathrm{~nm}$ by calcining at $1100{ }^{\circ} \mathrm{C}$. The activation energy for crystallite growth was found to be $89 \pm 14 \mathrm{~kJ} / \mathrm{mol}$. Dilatometric measurements of compacts of 1a show a distinctive two-step behaviour of the densification. The shrinkage starts at about $610{ }^{\circ} \mathrm{C}$. Dense ceramic bodies with relative densities $\geq 90 \%$ can be obtained after isothermal sintering at $1550{ }^{\circ} \mathrm{C}$ for $1 \mathrm{~h}$ and $1450{ }^{\circ} \mathrm{C}$ for $10 \mathrm{~h}$, respectively. On the basis of diffuse reflectance spectra the optical band gap of $\mathrm{MgFe}_{2} \mathrm{O}_{4}$ calcined at 550 ${ }^{\circ} \mathrm{C}$ (1a) was determined as $2.38 \mathrm{eV}$ and was found to decrease with raising calcination temperature and in turn increasing particle size to $2.16 \mathrm{eV}$ (calcination at $1100{ }^{\circ} \mathrm{C}, \mathbf{1 d}$ ). Ceramic bodies reveal optical band gaps at $2.1 \mathrm{eV}$.

Powder 1a shows a saturation magnetization of $20 \mathrm{emu} / \mathrm{g}$ at $300 \mathrm{~K}$. Increasing calcination temperatures to $900{ }^{\circ} \mathrm{C}$ cause a raising saturation magnetization up to $37.7 \mathrm{emu} / \mathrm{g}$, whereas $\mathrm{M}-\mathrm{H}$ loops at $10 \mathrm{~K}$ reveal saturation magnetization up to $50 \mathrm{emu} / \mathrm{g}$. We found a small shift (exchange bias) of the hysteresis loops depending on the crystallite size at $10 \mathrm{~K}$. The $\mathrm{MgFe}_{2} \mathrm{O}_{4}$ nano-sized samples show a typical superparamagnetic behaviour. They show the formation of hysteresis loops below the blocking temperature, whereas above the blocking temperature the hysteresis behaviour disappeared.

The saturation magnetization at $300 \mathrm{~K}$ of the obtained ceramic bodies varies only slightly with temperature and soaking time and lies between 25 and $28 \mathrm{emu} / \mathrm{g}$.

The $\mathrm{MgFe}_{2} \mathrm{O}_{4}$ powders show different magnetic properties depending on their particle sizes. This offers the possibility to modify the magnetoelectric coupling phenomena in multiferroic 
composites. Additionally, the superparamagnetic samples are potential candidates for applications as ferrofluid or contrast medium in the magnetic resonance tomography.

\section{Acknowledgements}

The authors thank Dr. Th. Müller for TG/MS-DTA and Dr. L. Jäger for UV-VIS measurements. Financial support by the German Science Foundation within the Collaborative Research Centre (SFB 762) "Functionality of Oxide Interfaces" is gratefully acknowledged.

\section{Table 1}

BET surface area, particle-/crystallite size and root-meansquare-strain ( $\varepsilon$ ) of $\mathrm{MgFe}_{2} \mathrm{O}_{4}$ powders

\begin{tabular}{llllll}
\hline Sample & $\begin{array}{l}\text { Calcination } \\
\text { procedure }\end{array}$ & $\begin{array}{l}\mathrm{S}_{\mathrm{BET}} \\
\left(\mathrm{m}^{2} / \mathrm{g}\right)\end{array}$ & $\begin{array}{l}\mathrm{d}_{\mathrm{BET}} \\
(\mathrm{nm})\end{array}$ & $\begin{array}{l}\mathrm{d}_{\text {cryst }} \\
(\mathrm{nm})\end{array}$ & $\begin{array}{l}\varepsilon \\
\left(\mathrm{x} 10^{3}\right)\end{array}$ \\
\hline $\mathbf{1 a}$ & $550{ }^{\circ} \mathrm{C} / 2 \mathrm{~h}$ & 60.6 & 22 & 9 & 5.5 \\
$\mathbf{1 b}$ & $600^{\circ} \mathrm{C} / 2 \mathrm{~h}$ & 39.6 & 34 & 11 & 3.9 \\
$\mathbf{1 c}$ & $700{ }^{\circ} \mathrm{C} / 2 \mathrm{~h}$ & 19.1 & 70 & 13 & 3.4 \\
$\mathbf{1 d}$ & $800^{\circ} \mathrm{C} / 2 \mathrm{~h}$ & 6.0 & 223 & 32 & 1.3 \\
$\mathbf{1 e}$ & $900^{\circ} \mathrm{C} / 2 \mathrm{~h}$ & 3.2 & 418 & 57 & 0.8 \\
$\mathbf{1 f}$ & $1000^{\circ} \mathrm{C} / 2 \mathrm{~h}$ & 2.6 & 514 & 86 & 0.8 \\
$\mathbf{1 g}$ & $1100^{\circ} \mathrm{C} / 2 \mathrm{~h}$ & 2.3 & 573 & 129 & 0.8 \\
$\mathbf{2}$ & $1250^{\circ} \mathrm{C} / 2 \mathrm{~h}$ & 1.1 & 1215 & - & - \\
\hline
\end{tabular}

1) calculated from the specific surface area

2) volume-weighted average crystallite size (Scherrer equation)

\section{Table 2}

Saturation magnetization $\left(\mathrm{M}_{\mathrm{s}}\right)$, coercivity $\left(\mathrm{H}_{\mathrm{c}}\right)$ and remanence $\left(\mathrm{M}_{\mathrm{r}}\right)$ of synthesized $\mathrm{MgFe}_{2} \mathrm{O}_{4}$ powders at $300 \mathrm{~K}$ and $10 \mathrm{~K}$

\begin{tabular}{lcccccc}
\hline Sample & $\mathrm{M}_{\mathrm{s}}(\mathrm{emu} / \mathrm{g})$ & \multicolumn{2}{c}{$\mathrm{H}_{\mathrm{c}}(\mathrm{Oe})$} & $\Delta \mathrm{H}_{\mathrm{c}}(\mathrm{Oe})^{2)}$ & \multicolumn{2}{c}{$\mathrm{M}_{\mathrm{r}}(\mathrm{emu} / \mathrm{g})$} \\
\hline $300 \mathrm{~K}$ & $10 \mathrm{~K}$ & $300 \mathrm{~K}$ & $10 \mathrm{~K}^{1)}$ & $10 \mathrm{~K}$ & $300 \mathrm{~K}$ & $10 \mathrm{~K}^{1)}$
\end{tabular}




\begin{tabular}{llllllll}
\hline 1a & 20.0 & 28.3 & $\sim 0$ & 950 & 81 & $\sim 0$ & 6.6 \\
$\mathbf{1 b}$ & 23.0 & 31.8 & $\sim 0$ & 671 & 67 & $\sim 0$ & 7.5 \\
$\mathbf{1 c}$ & 28.3 & 38.4 & 15.2 & 390 & 33 & 0.4 & 9.7 \\
$\mathbf{1 d}$ & 35.5 & 47.4 & 67.2 & 220 & 11 & 3.0 & 9.5 \\
$\mathbf{1 e}$ & 37.7 & 50.4 & 56.6 & 146 & 3.5 & 2.8 & 7.9 \\
$\mathbf{1 f}$ & 36.9 & 49.5 & 63.4 & 143 & 3 & 2.9 & 7.5 \\
$\mathbf{1 g}$ & 33.9 & 48.6 & 10.5 & 62 & 1 & 0.6 & 5.2 \\
\hline
\end{tabular}

1) $\mathrm{H}_{\mathrm{c}}$ and $\mathrm{M}_{\mathrm{r}}$ (absolute values) were determined from the decreasing field

2) calculated from $\Delta \mathrm{H}_{\mathrm{c}}=\left|0.5\left(\mathrm{H}_{\mathrm{c}(\mathrm{df})}+\mathrm{H}_{\mathrm{c}(\mathrm{if})}\right)\right|$

Table 3

Saturation magnetization $\left(\mathrm{M}_{\mathrm{s}}\right)$ of ceramic bodies from powder 1a at $300 \mathrm{~K}$ and $10 \mathrm{~K}$

\begin{tabular}{llll}
\hline Sintering condition & \multirow{2}{*}{ Grain-size range $(\mu \mathrm{m})$} & \multicolumn{2}{c}{$\mathrm{M}_{\mathrm{s}}(\mathrm{emu} / \mathrm{g})$} \\
& & $300 \mathrm{~K}$ & $10 \mathrm{~K}$ \\
\hline $1450^{\circ} \mathrm{C} / 1 \mathrm{~h}$ & $3-15$ & 28.2 & 35.9 \\
$1500^{\circ} \mathrm{C} / 1 \mathrm{~h}$ & $3.5-15$ & 26.5 & 33.5 \\
$1550^{\circ} \mathrm{C} / 1 \mathrm{~h}$ & $6-18$ & 25.9 & 32.7 \\
$1600^{\circ} \mathrm{C} / 1 \mathrm{~h}$ & $6-25$ & 26.6 & 33.4 \\
$1450^{\circ} \mathrm{C} / 10 \mathrm{~h}$ & $4-28$ & 27.3 & 34.5 \\
$1500^{\circ} \mathrm{C} / 10 \mathrm{~h}$ & $5-42$ & 25.3 & 31.8 \\
$1550^{\circ} \mathrm{C} / 10 \mathrm{~h}$ & $16-50$ & 26.0 & 32.7 \\
\hline
\end{tabular}



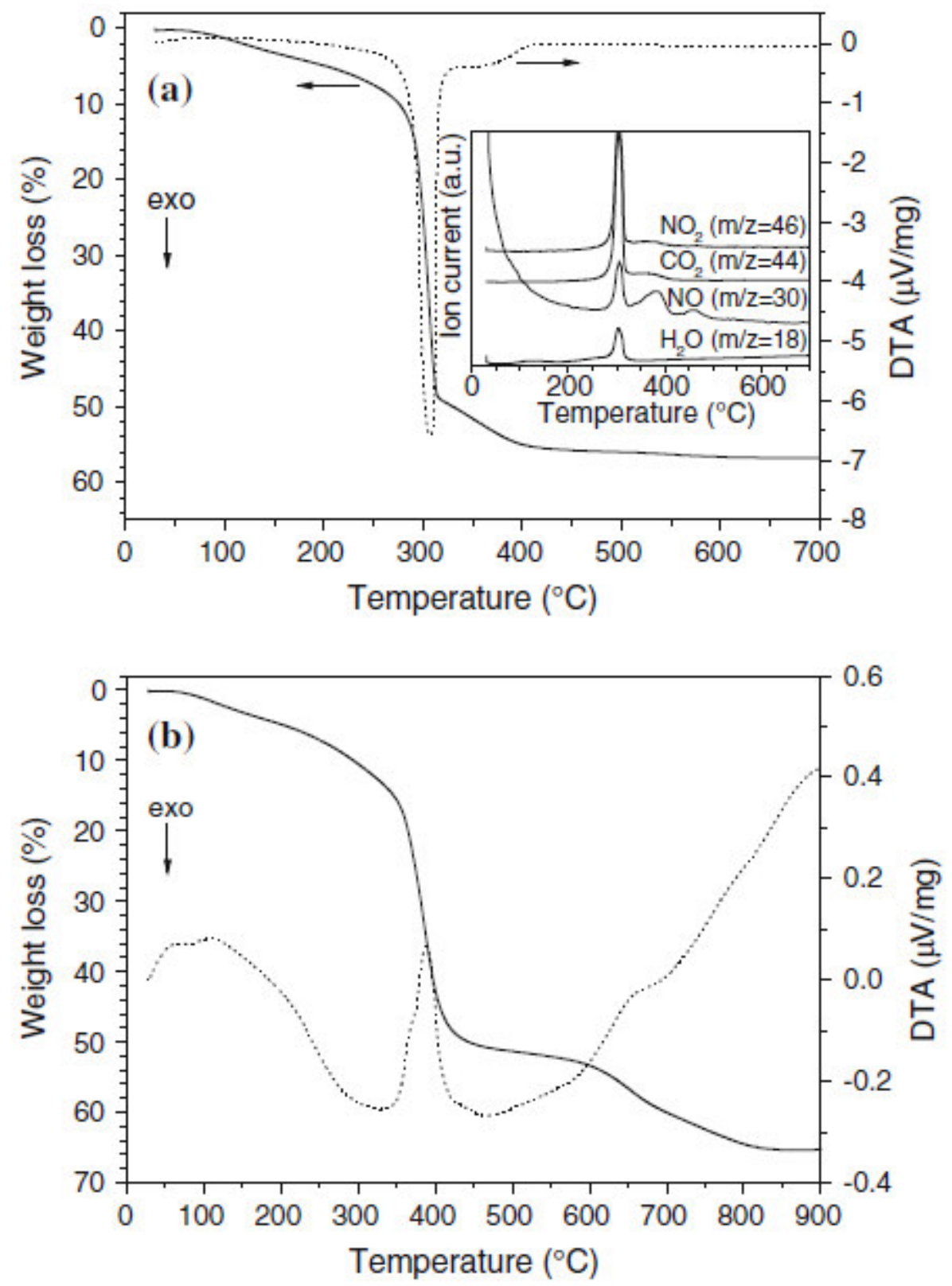

Fig. 1 Simultaneous TG-MS and DTA investigations (heating rate $5 \mathrm{~K} / \mathrm{min}$ ) of a preheated (MgFe)-gel in air (a). The inset in a shows the corresponding MS signals. TG/DTA curves in argon atmosphere (b) 


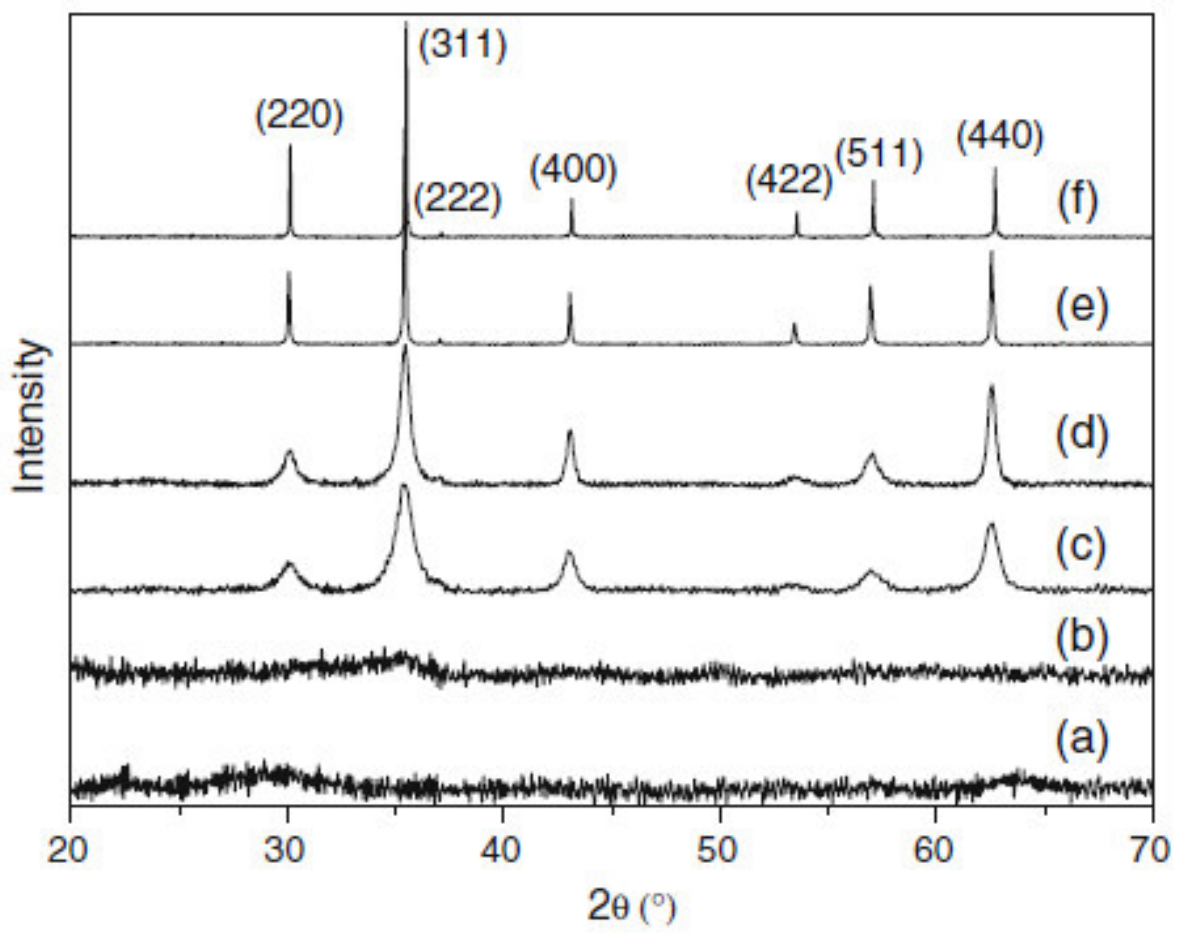

Fig. 2 Room temperature XRD patterns of the (MgFe)-gel (a) and resulting calcination products $(b-f)$ at various temperatures (soaking time $2 \mathrm{~h}$, rate $5 \mathrm{~K} / \mathrm{min}$ ): $b 400{ }^{\circ} \mathrm{C}, c 550{ }^{\circ} \mathrm{C}$ (powder 1a), $d 700{ }^{\circ} \mathrm{C}$ (powder 1c), $e 1000{ }^{\circ} \mathrm{C}$ (powder 1f). Graph $f$ shows the XRD pattern of powder 2

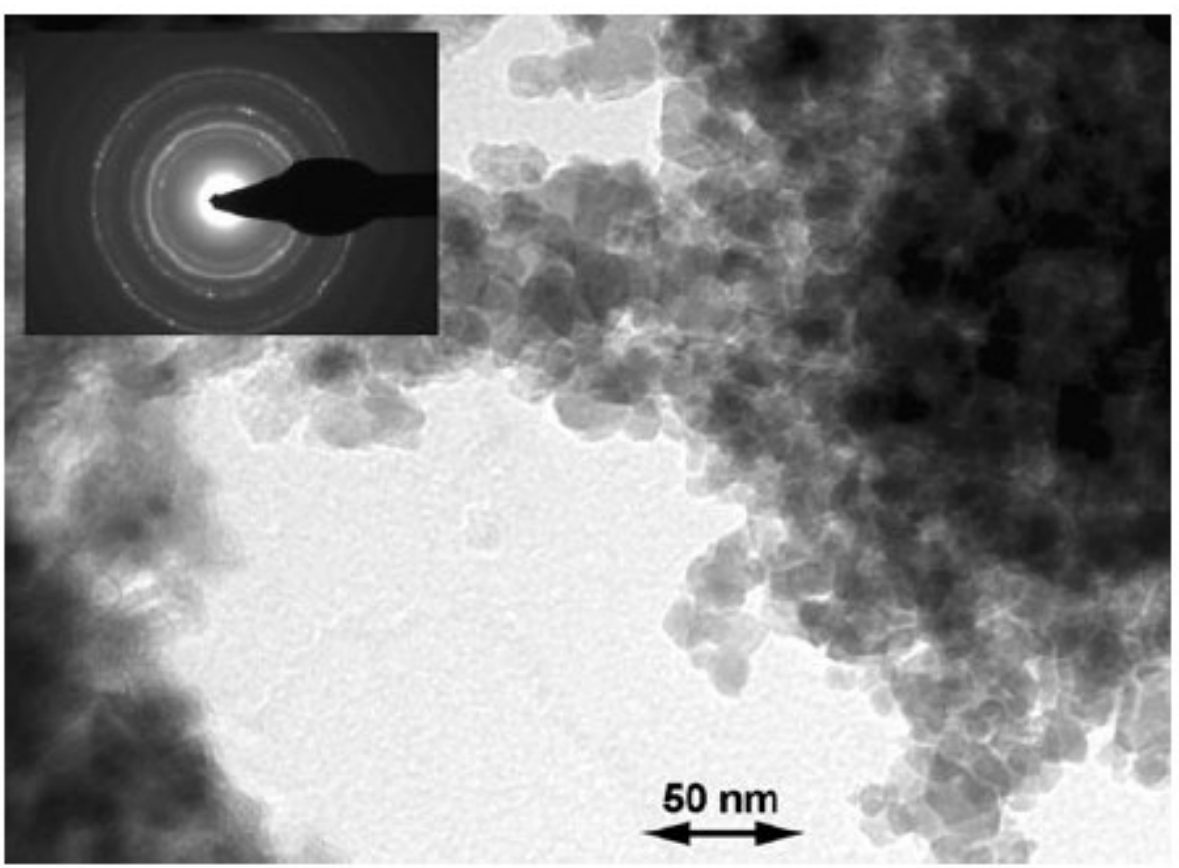

Fig. 3 TEM image of powder 1a 

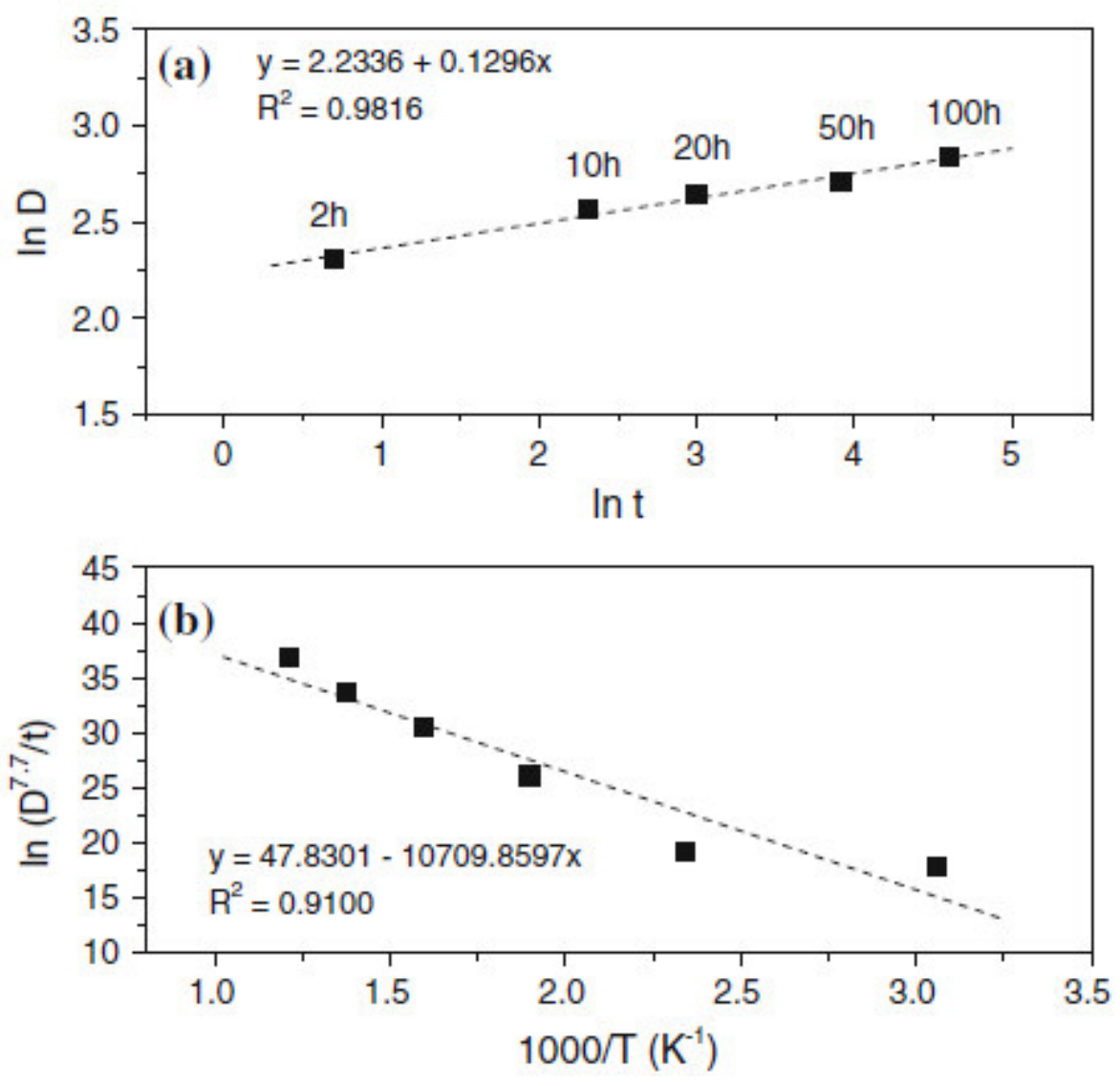

Fig. 4 a $\ln D$ (crystallite size) versus $\ln t$ (calcination time) for $\mathrm{MgFe}_{2} \mathrm{O}_{4}$ calcined at $600{ }^{\circ} \mathrm{C}$, (b) plot of $\ln \left(D^{7.7} / t\right)$ as a function of $1 / T$ for samples calcined for $2 \mathrm{~h}$ 


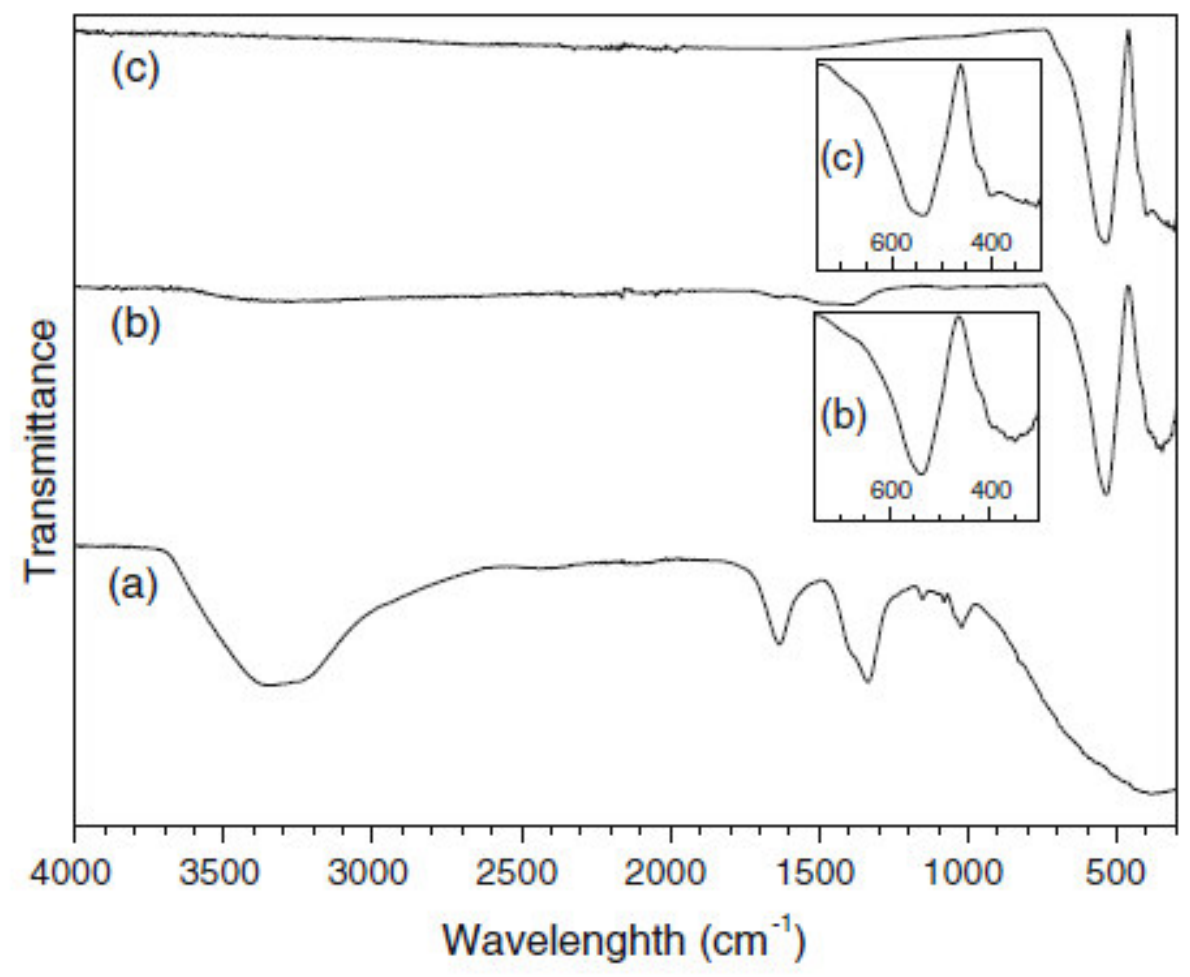

Fig. 5 FT-IR spectra (ATR technique) of (a) (MgFe)-gel, (b) powder 1a and $(c)$ powder if

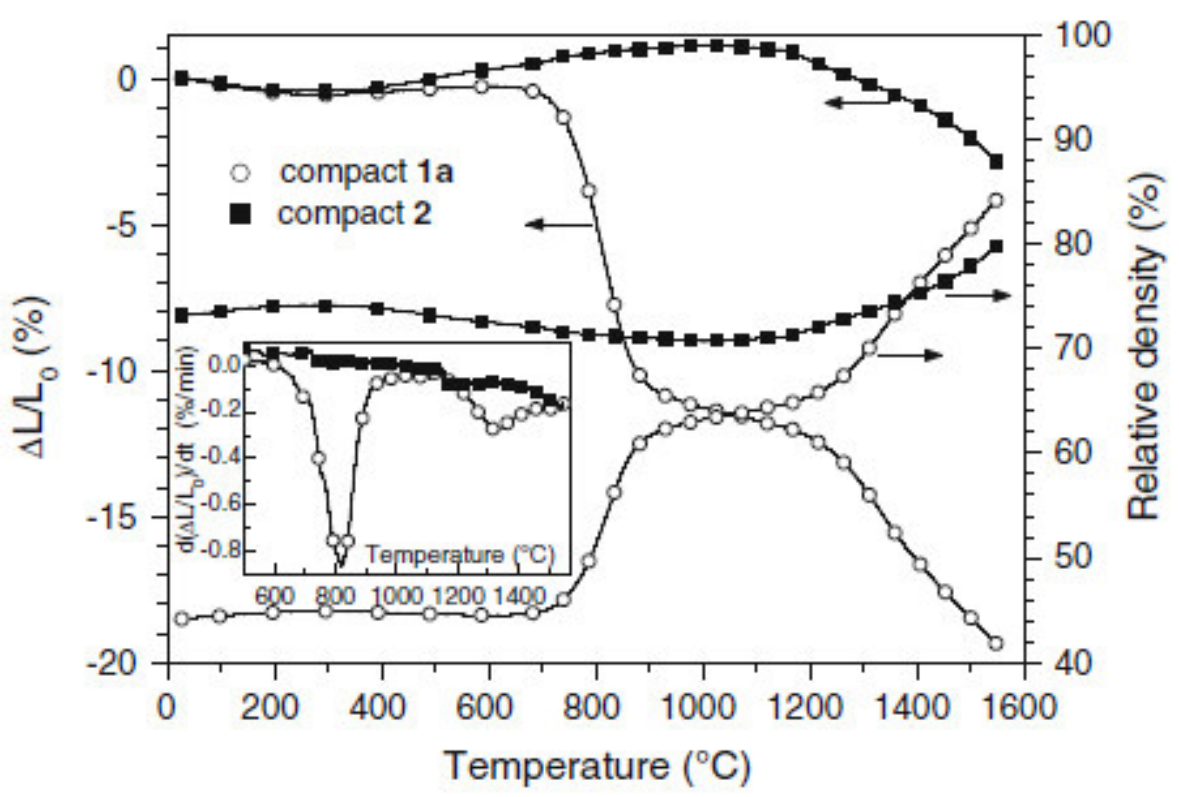

Fig. 6 Non-isothermal dilatometric measurements of green bodies of la and 2 in flowing air (heating rate $10 \mathrm{~K} / \mathrm{min}$ ). The relative densities were calculated assuming an isotropic shrinkage behaviour. The inset ;hows the relative shrinkage rates $\left(\mathrm{d}\left(\Delta L / L_{0}\right) / \mathrm{d} t\right)$. The green densities ire $2.0 \mathrm{~g} / \mathrm{cm}^{3}$ (1a) and $3.3 \mathrm{~g} / \mathrm{cm}^{3}(2)$, respectively 


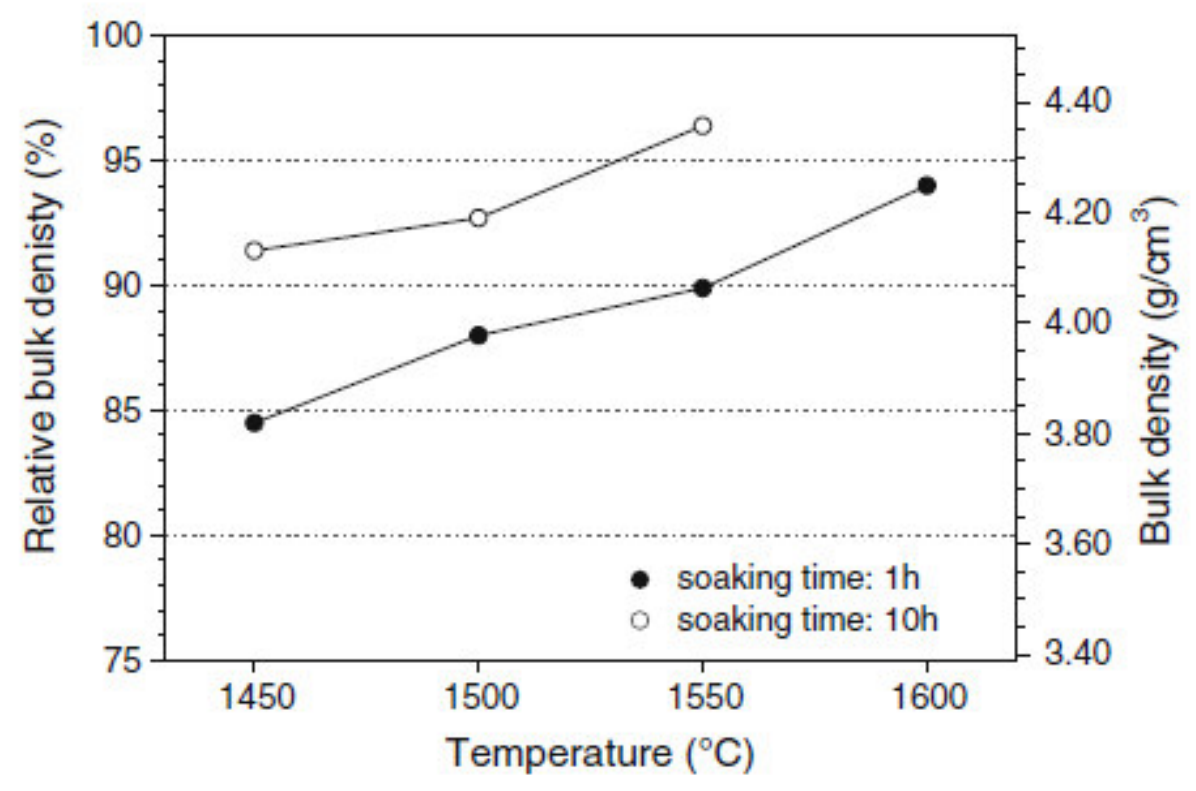

Fig. 7 Final bulk densities versus sintering temperature of ceramic bodies of 1a (soaking time: 1 and $10 \mathrm{~h}$, heating-/cooling rate: $10 \mathrm{~K} /$ $\min )$
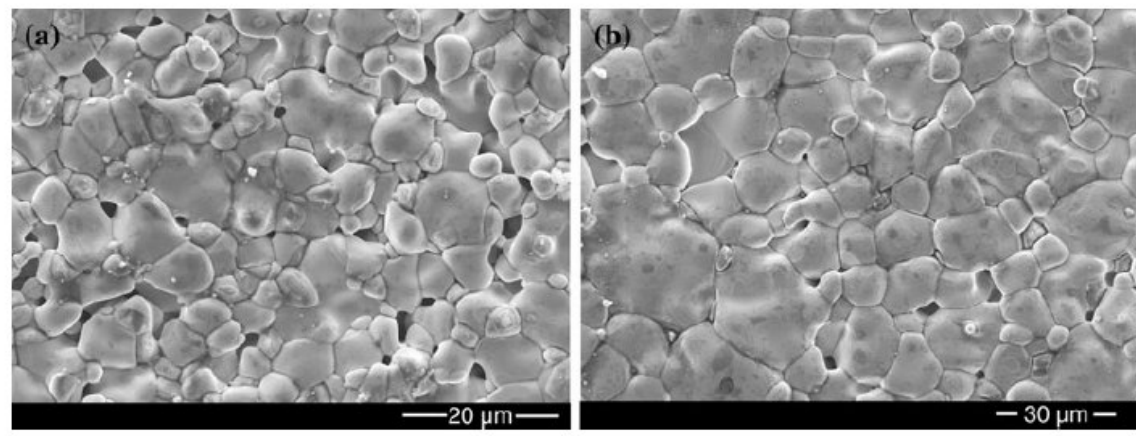

Fig. 8 SEM surface images of ceramic bodies of 1a after isothermal sintering at $1450{ }^{\circ} \mathrm{C}$ (heating-/cooling rate: $10 \mathrm{~K} / \mathrm{min}$ ): a soaking time $1 \mathrm{~h}$ and $\mathbf{b}$ soaking time $10 \mathrm{~h}$ 


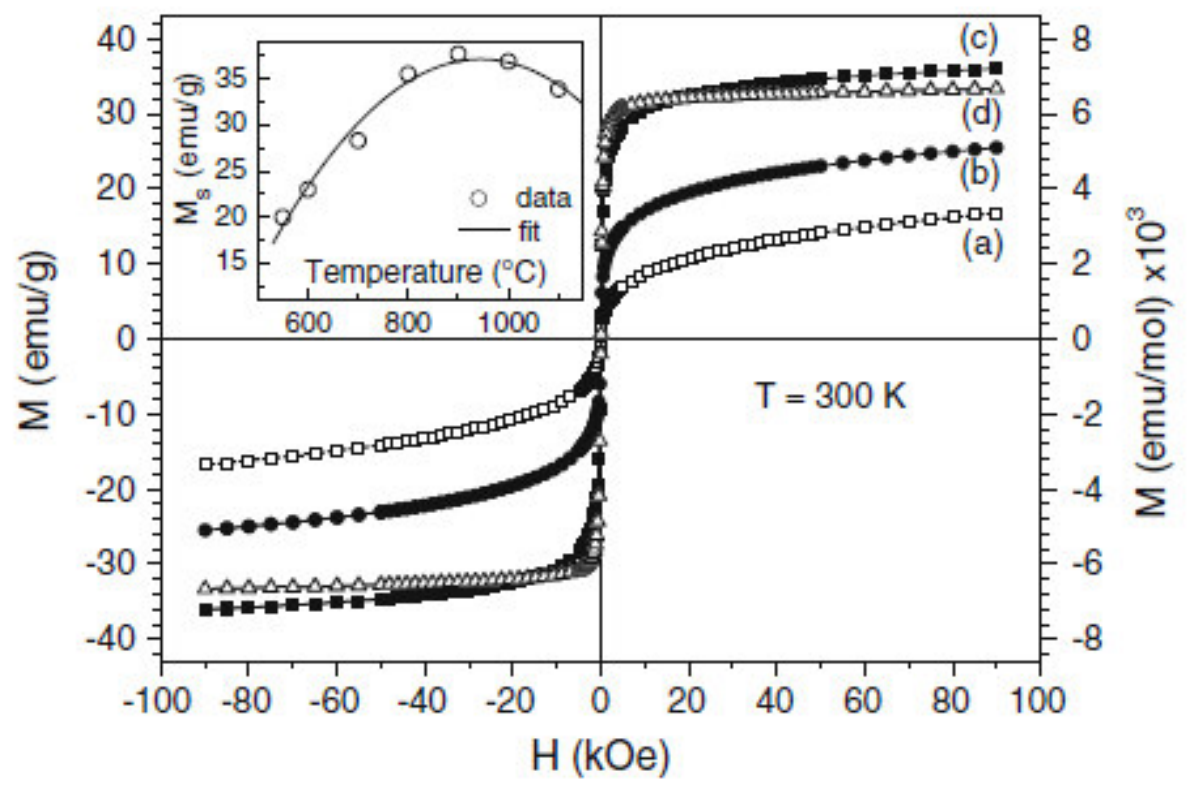

Fig. 9 Magnetization $(M)$ versus applied magnetic field $(H)$ of various $\mathrm{MgFe}_{2} \mathrm{O}_{4}$ powders at $300 \mathrm{~K}$. $a$ Powder $1 \mathrm{a}, b$ powder $1 \mathrm{c}$, $c$ powder $1 \mathrm{e}$ and $d$ powder $1 \mathrm{~g}$. The inset shows the saturation magnetization $\left(M_{\mathrm{s}}\right)$ depending on calcination temperature

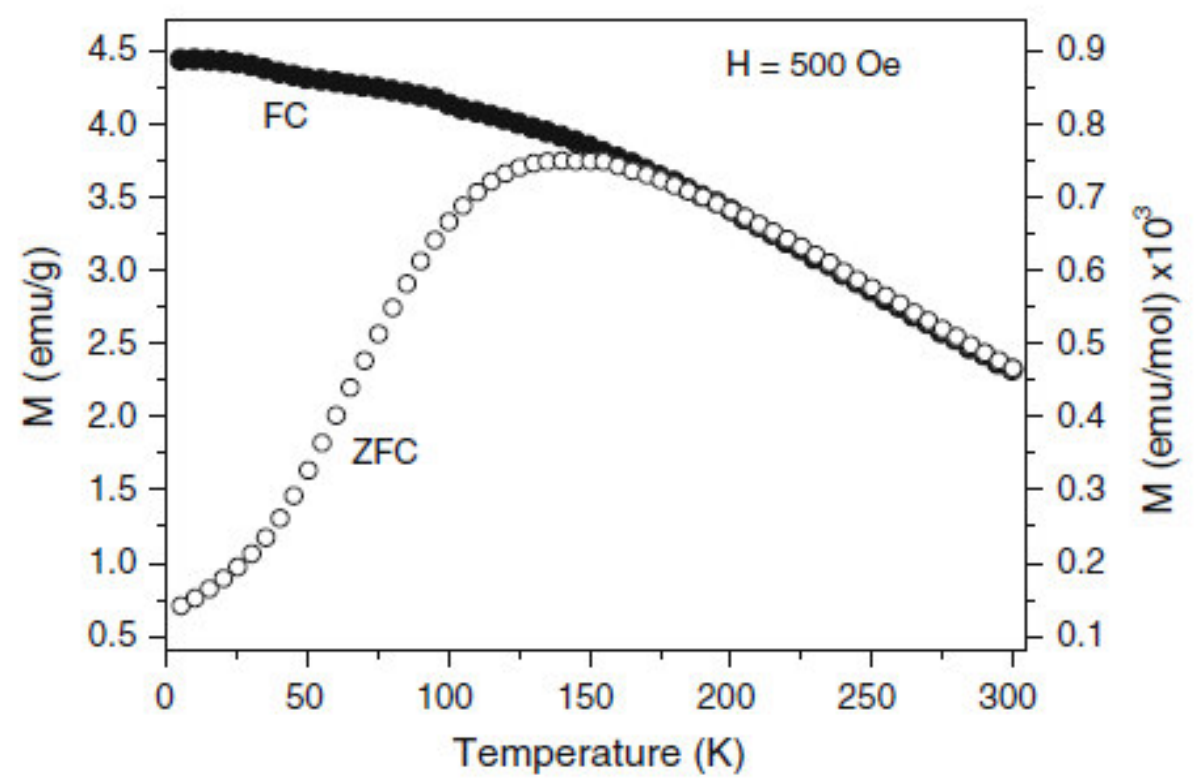

Fig. 10 Temperature dependence of the magnetization for zero-fieldcooled (ZFC) and field-cooled (FC) powder 1a in the range 5-300 K 


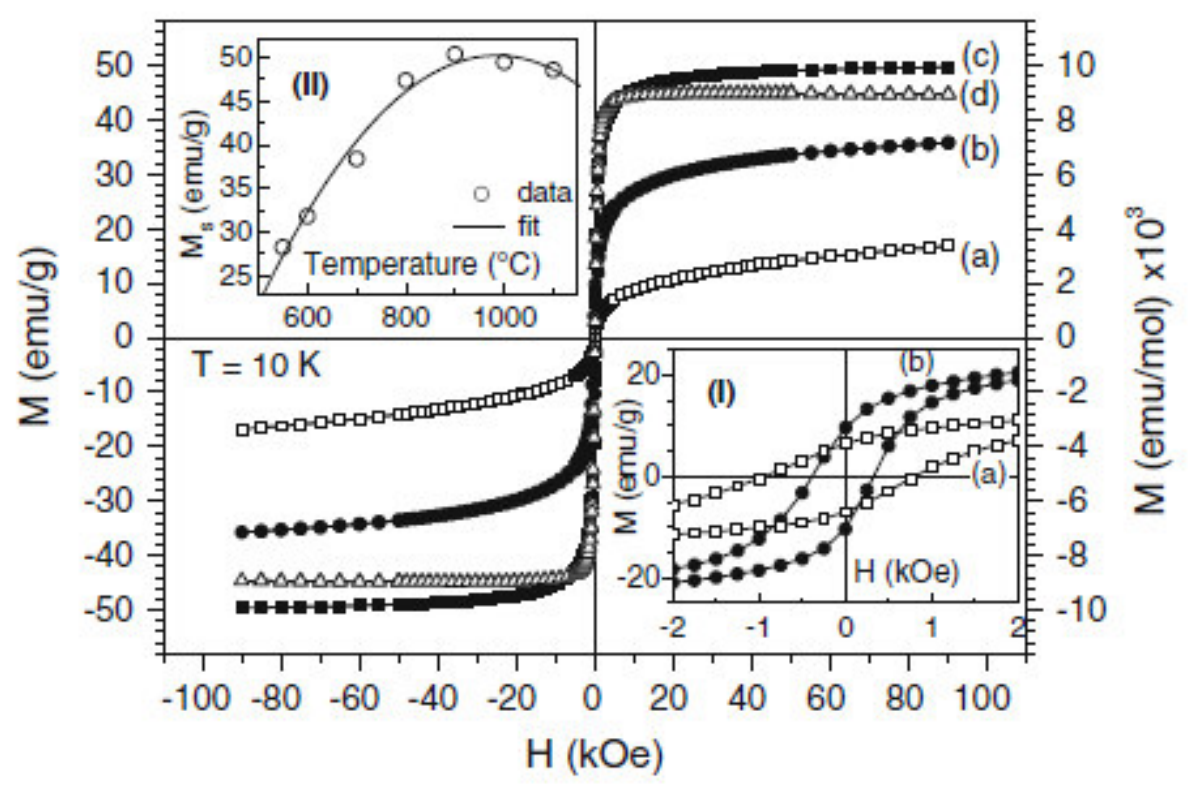

Fig. 11 Magnetization $(M)$ versus applied magnetic field $(H)$ of various $\mathrm{MgFe}_{2} \mathrm{O}_{4}$ powders at $10 \mathrm{~K}$. $a$ Powder $1 \mathrm{a}, b$ powder $1 \mathrm{c}$, $c$ powder $1 \mathrm{e}$ and $d$ powder 1g. Inset (I) shows the saturation magnetization $\left(M_{\mathrm{s}}\right)$ depending on calcination temperature and inset (II) shows $M$ versus $H$ in a small field range of powders 1a $a$ and $1 \mathrm{c} b$

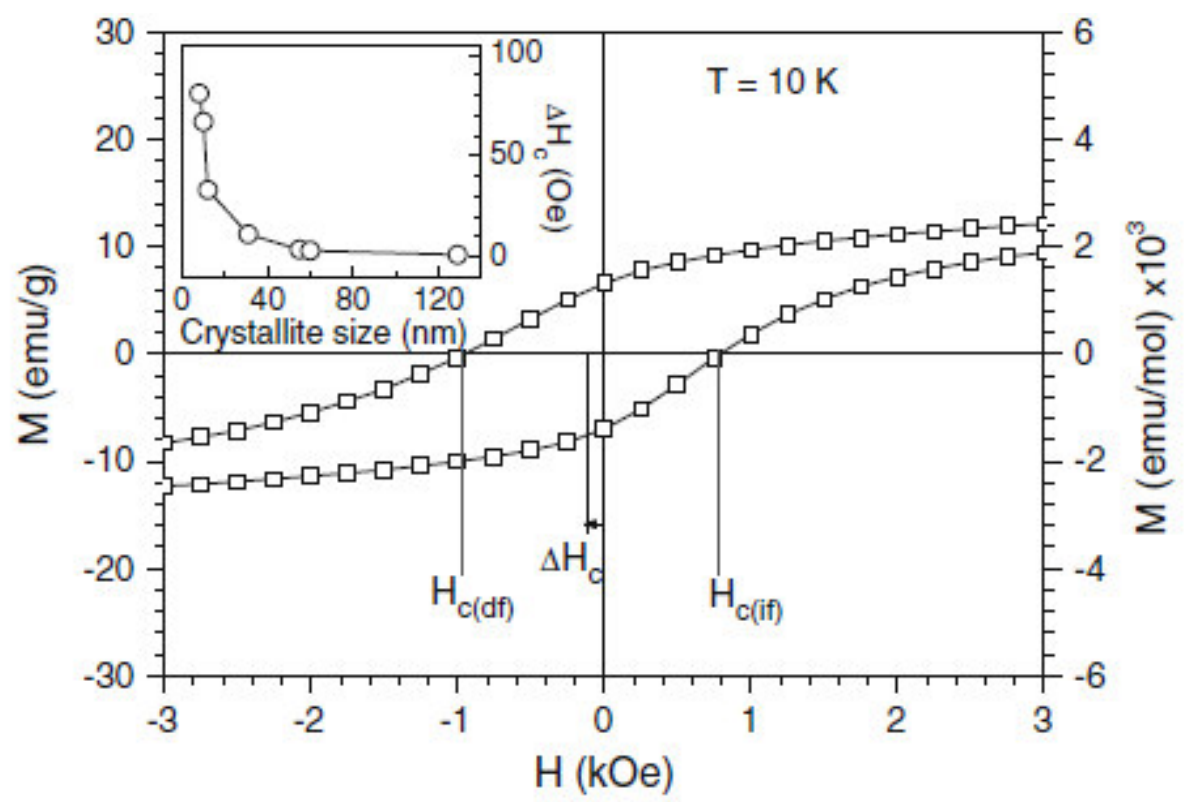

Fig. 12 Magnetization $(M)$ versus applied magnetic field $(H)$ of powder 1a at $10 \mathrm{~K}$ in the range of small magnetic fields. The coercivity shift $\left(\Delta H_{\mathrm{c}}\right)$, the coercivity at decreasing field $\left(H_{\mathrm{c}(\mathrm{df})}\right)$ and the coercivity at increasing field $\left(H_{\mathrm{c}(\mathrm{if})}\right)$ are indicated in the figure. The inset shows the coercivity shift $\left(\Delta H_{\mathrm{c}}\right)$ depending on the crystallite size 


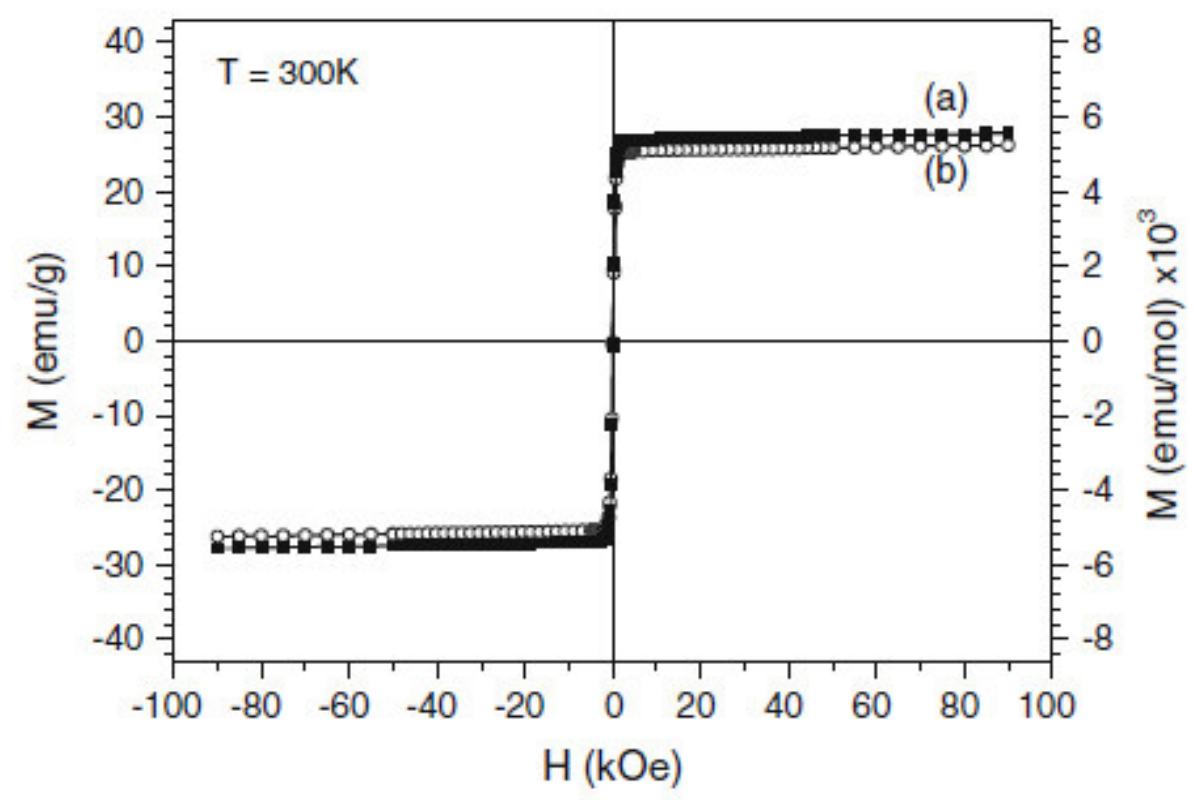

Fig. 13 Magnetization $(M)$ versus applied magnetic field $(H)$ of ceramic bodies from powder 1a at $300 \mathrm{~K}$. $a$ Sintering at $1450{ }^{\circ} \mathrm{C}$ for $1 \mathrm{~h}$ and $b$ sintering at $1600{ }^{\circ} \mathrm{C}$ for $1 \mathrm{~h}$

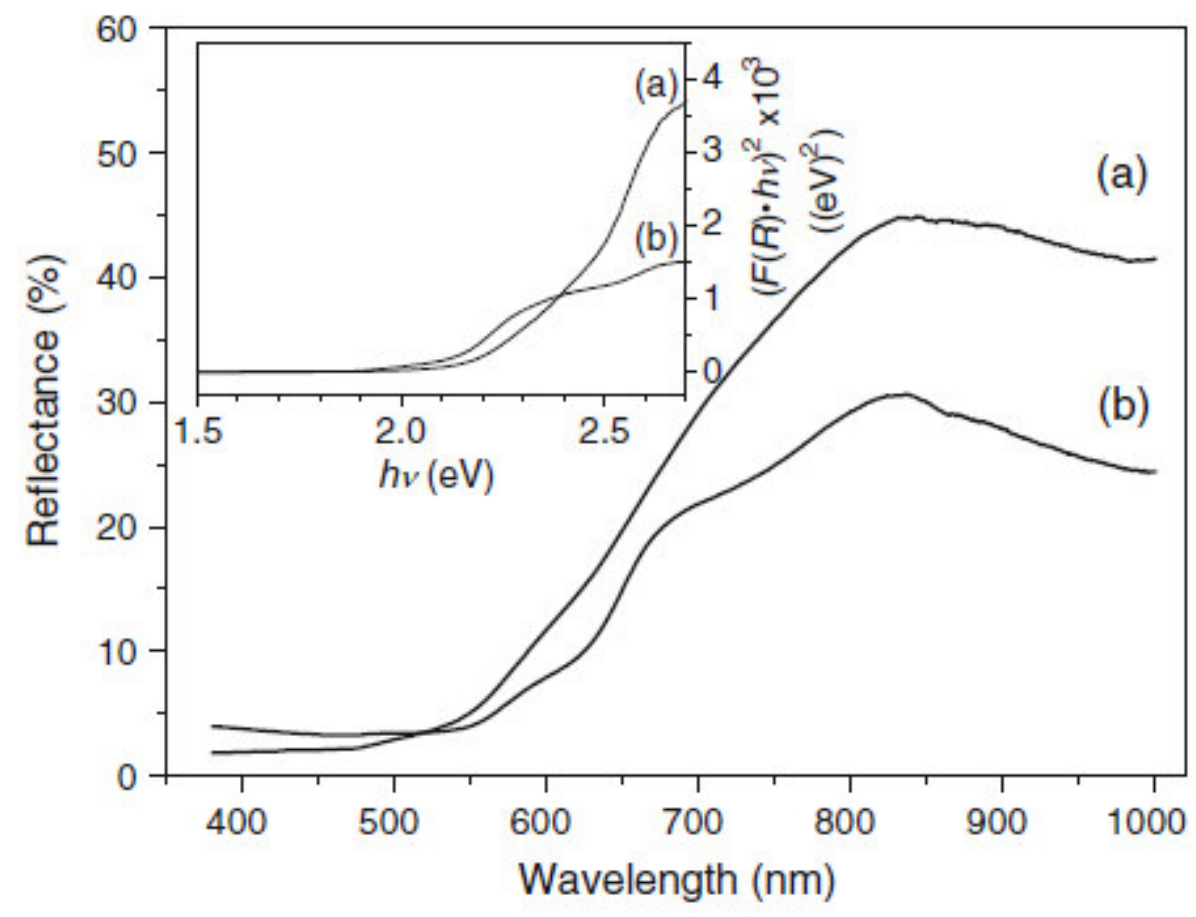

Fig. 14 Diffuse reflectance versus wavelength for powder 1a $(a)$ and a corresponding ceramic body sintered at $1450{ }^{\circ} \mathrm{C}$ for $1 \mathrm{~h}(b)$. The inset shows the graphical representation of $(F(R) \cdot h v)^{2}$ versus $h v$ 


\section{References}

[1] Rane KS, Verenkar VMS, Sawant PY (2008) Bull Mater Sci 24: 323-330.

[2] Goldman A (2006) Modern Ferrite Technology. Springer Science+Business Media Inc., New York.

[3] Ma N, Yue Y, Hua W, Gao Z (2003) Appl Catal A 251: 39-47.

[4] Ma X, Sun H, Liu W, Zheng M (2007) Fresen Environ Bull 16: 745-748.

[5] Lee YH, Lee GD, Park SS, Hong SS (2005) React Kinet Catal Lett 84: 311-317.

[6] Dom R, Subasri R, Radha K, Borse PH (2011) Solid State Commun 151: 470-473.

[7] Xiong C, Chen Q, Lu W, Gao H, Lu W, Gao Z (2000) Catal Lett 69: 231-236.

[8] Gusmano G, Montesperelli G, Nunziante P, Traversa E (1993) J Mater Sci 28: 61956198.

[9] Liu YL, Liu ZM, Yang Y, Yang HF, Shen GL, Yu RQ (2005) Sens Actuators B 107: 600-604.

[10] Benko FA, Koffyberg EP (1986) Mater Res Bull 21: 1183-1988.

[11] Candeia RA, Souza MAF, Bernardi MIB, Maestrelli SC, Santos IMG, Souza AG, Longo E (2006) Mater Res Bull 41: 183-190.

[12] Kalendová A (2000) Prog Org Coat 38: 199-206.

[13] Mizoe K, Takiguchi T, Arahira F, Ito M (2005) Toner and Image Forming Method. US-Pat. 6897001 B2.

[14] Watanabe Y, Sato K, Yukumi S, Yoshida M, Yamamoto Y, Doi T, Sugishita H, Naohara T, Maehara T, Aono H, Kawachi K (2009) Bio-Med Mater Eng 19: 101-110.

[15] Yukumi S, Watanabe Y, Horiuchi A, Doi T, Sato K, Yoshida M, Maehara T, Aono H, Naohara T, Kawachi K (2008) Anticancer Res 28: 69-74.

[16] Okawa H, Lee JH, Hotta T, Ohara S, Takahashi S, Shibahashi T, Yamamasu Y (2004) J Power Source 131: 251-255. 
[17] Tadi R, Kim YI, Sarkar D, Kim C, Ryu KS (2011) J Magn Magn Mater 323: 564-568.

[18] O’Neill HStC, Annersten H, Virgo D (1992) Am Mineral 77: 725-740.

[19] Gateshki M, Petkov V, Pradhan SK, Vogt T (2005) J Appl Cryst 38: 772-779.

[20] R.J. Harrison, A. Putnis, Phys. Chem. Minerals 26 (1999) 322-332.

[21] Sepelák V, Bergmann I, Feldhoff A, Litterst FJ, Becker KD, Cadogan JM, Hofmann M, Hoelzel M, Wang JL, Avdeev M, Campbell SJ (2010) Hyperfine Interact 198: 6771.

[22] Berchmans LJ, Selvan RK, Kumar PNS, Augustin CO (2004) J Magn Magn Mater 279: 103-110.

[23] Chandradass J, Jadhav AH, Kim H (2012) Appl Surf Sci 258: 3315-3320.

[24] Iqbal MJ, Ahmad Z, Melikhov Y, Nlebedim IC (2012) J Magn Magn Mater 324: $1088-1094$.

[25] Hoque SM, Hakim MA, Mamun A, Akhter S, Hasan MT, Paul DP, Chattopadhayay K (2011) Mater Sci Appl 2: 1564-1571.

[26] Akhtar MJ, Younas M (2012) Solid State Sci 14: 1536-1542.

[27] Khot VM, Salunkhe AB, Phadatare MR, Pawar SH (2012) Mater Chem Phys 132: $782-787$.

[28] Maensiri S, Sangmanee M, Wiengmoon A (2009) Nanoscale Res Lett 4: 221-228.

[29] Kraus W, Nolze G (1998) Powder Diffr 13: 256-259.

[30] Program WinXPOW v1.06 (1999). Stoe \& Cie GmbH, Darmstadt.

[31] Stokes AR, Wilson AJC (1994) Proc Phys Soc 56: 174-181.

[32] Allred VD, Buxton SR, McBride JP (1957) J Phys Chem 61: 117-120.

[33] PDF 2 (International Centre for Diffraction Data, Pennsylvania) (2001). $\mathrm{MgFe}_{2} \mathrm{O}_{4}$ [711232], $\mathrm{Fe}_{2} \mathrm{O}_{3}$ [72-469], $\mathrm{Fe}$ [6-696], $\mathrm{FeO}$ [6-615], $\mathrm{Mg}_{1-\mathrm{x}} \mathrm{Fe}_{\mathrm{x}} \mathrm{O}$ [35-1393] .

[34] Qian YT, Kershaw R, Dwight K, Wold A (1983) Mater Res Bull 18: 543-548. 
[35] Buscaglia MT, Bassoli M, Buscaglia V, Alessio R (2005) J Am Ceram Soc 88: 23742379.

[36] Cun W, Xinming W, Jincai Z, Bixian M, Guoying S, Ping'an P, Jiamo F (2002) J Mater Sci 37: 2989-2996.

[37] Changa PR, Zheng P, Liu B, Anderson DP, Yu J, Ma X (2011) J Hazard Mater 186: $2144-2150$

[38] Nakamoto K (1986) Infrared and Raman Spectra of Inorganic and Coordination Compounds. John Wiley \& Sons, USA.

[39] Fang JM, Fowler PA, Tomkinson J, Hill CAS (2002) Carbohydr Polym 47: 245-252.

[40] Gadkari AB, Shinde TJ, Vasambekar PN (2010) J Mater Sci Mater Electron 21: 96103.

[41] Josyulu OS and Sobhanadri J (1981) phys stat sol (a) 65: 479-483.

[42] Gaudon M, Pailhe N, Wattiaux A, Demourgues A (2009) Mater Res Bull 44: 479-484.

[43] Köferstein R, Jäger L, Zenkner M, Ebbinghaus SG (2009) J Eur Ceram Soc 29: $2317-2324$

[44] Schatt W (1992) Sintervorgänge. VDI-Verlag, Düsseldorf.

[45] Hirata Y, Hara A, Aksay IA (2009) Ceram Int 35: 2667-2674.

[46] Kirichok PP, Antoshchuk AP (1977) Izv Akad Nauk Neorg Mater 13: 1327-1330.

[47] Phillips B, Somiya S, Muan A (1961) J Am Ceram Soc 44: 167-169.

[48] Ahmed YMZ, Ewais EMM, Zaki ZI (2010) J Alloy Comp 489: 269-274.

[49] Özgür Ü, Alivov Y, Morkoc H (2009) J Mater Sci Mater Electron 20: 789-834.

[50] Chikazumi S (2005) Physics of Ferromagnetism. Oxford University Press.

[51] Krissman CJ, Harrison SE (1956) Phys Rev 103: 857-860.

[52] Antic B, Jovic N, Pavlovic MB, Kremenovic A, Manojlovic D, Vucinic-Vasic M, Nikolic AS (2010) J Appl Phys 107: 043525. 
[53] Rashad MM (2007) J Mater Sci 42: 5248-5255.

[54] Chen C, Rondinone AJ, Chakoumakos BC, Zhang ZJ (1999) J Magn Magn Mater 194: $1-7$.

[55] Chen Q and Zhang ZJ (1998) Appl Phys Lett 73: 3156-3158.

[56] Nogues J and Schuller IK (1999) J Magn Magn Mater 192: 203-232.

[57] Sepelak V, Feldhoff A, Heitjans P, Krumeich F, Menzel D, Litterst FJ, Bergmann I, Becker KD (2006) Chem Mater 18: 3057-3067.

[58] Sepelak V, Baabe D, Mienert D, Litterst FJ, Becker KD (2003) Scr Mater 48: 961-966.

[59] Kodama RH, Makhlouf SA, Berkowitz AE (1997) Phys Rev Lett 79: 1393-1396.

[60] Nipan GD, Ketsko VA, Stognij AI, Trukhanov AV, Koltsova TN, Kopeva MA, Elesina LV, Kuznetsov NT (2010) Inorg Mater 46: 429-433.

[61] Kim HG, Borse PH, Jang JS, Jeong ED, Jung OS, Suh YJ, Lee JS (2009) Chem Commun 5889-5891.

[62] Kubelka P, Munk F (1931) Z. Techn. Phys. 11: 593-601.

[63] Kortüm G and Vogel J (1958) Z Phys Chem 18: 110-122.

[64] Nowak M, Kauch B, Szperlich P (2009) Rev Sci Instrum 80: 046107.

[65] McLean TP (1960) In: Gibson AF (ed) Progress in Semiconductors, Vol. 5, Heywood, London.

[66] Roduner E (2006) Chem Soc Rev 35: 583-592. 